\title{
Biological and geological dynamics over four years on a high-temperature sulfide structure at the Juan de Fuca Ridge hydrothermal observatory
}

\author{
Jozée Sarrazin ${ }^{1, *}$, Véronique Robigou ${ }^{2}$, S. Kim Juniper ${ }^{1}$, John R. Delaney ${ }^{2}$ \\ ${ }^{1}$ GÉOTOP/Université du Québec à Montréal, Case Postale 8888, succursale Centre-Ville, Montréal (Québec), Canada H3C 3P8 \\ ${ }^{2}$ School of Oceanography, University of Washington, Seattle, Washington 98195-7940, USA
}

\begin{abstract}
An extensive videoscopic study of a high-temperature sulfide structure on the Juan de Fuca Ridge (northeast Pacific) examined temporal variation in vent community distribution and links between faunal and environmental changes. Video imagery was acquired during a total of 5 manned submersible and ROV (remotely-operated vehicle) dive programs between 1991 and 1995. The structure was systematically mapped for each year of the study and a series of analytical tools was developed to quantify changes in biological and geological features and observable flow patterns. Results show: (1) heterogeneous faunal distribution, characterized by decimeter-scale patchiness and general absence of vertical gradients; (2) apparent links between community distribution, and environmental features such as fluid flow patterns, substratum and temperature/chemical conditions; (3) a significant influence of perturbations on community dynamics; (4) absence of directional biological succession at the time scale examined (years). Overall, these observations strongly suggest that many hydrothermal community changes are initiated by gradual and abrupt flow modifications. Results are compiled in a dynamic succession model for sulfide edifices where community transitions are driven by flow variations, and by biological processes operating at sub-annual time scales. We conclude by stressing the need for extended monitoring of short-term dynamics in order to understand the relationship between hydrothermal communities and their environment.
\end{abstract}

KEY WORDS: Hydrothermal ecology - Community structure - Spatio-temporal distribution - Flow patterns · Biological succession - Disturbances · Juan de Fuca Ridge · Endeavour Segment

\section{INTRODUCTION}

Changes in marine benthic community structure can result from the combined effects of biological interactions (predation, grazing and competition) and environmental factors (Paine 1966, Dayton 1971, Bélanger \& Cardinal 1977, Lubchenco \& Menge 1978, Young \& Young 1978, Nybakken 1988, Dai 1993, Rodriguez et al. 1993, Chapman \& Underwood 1994, Tanner et al. 1994, Williams 1994). For example, hard substrate community structure appears to be controlled by abiotic factors in zones where physico-chemical conditions are highly variable whereas biological interactions tend to shape communities in habitats where

•E-mail: d110644@er.uqam.ca environmental conditions are more constant and moderate (Dayton 1970, 1971. Connell 1972, 1978, 1985, Menge 1976, Menge \& Sutherland 1976, Lubchenco \& Menge 1978, Underwood 1981, Littler \& Littler 1984 , McGuinness 1988, McClanahan 1992, Boulding \& Van Alstyne 1993, Metaxas \& Scheibling 1993, Wootton 1993, Dethier 1994, Metaxas et al. 1994, Williams 1994). Community structuring by biotic and abiotic factors has been little studied in the deep-sea hydrothermal vent environment. Vent ecology is relatively young and basic questions about species distribution, tolerance, and colonization patterns are of considerable current interest (Tunnicliffe 1991).

The importance of biotic factors in structuring vent communities is poorly understood (Mullineaux et al. 1996). Hessler et al. (1988) attribute community changes 
over time at the Galapagos diffuse flow vents to biological interactions such as competition and/or predation rather than environmental conditions. The extreme nature of high-temperature hydrothermal habitats and the short time-scale at which change operates (Johnson et al. 1988a, b, 1994. McDuff et al. 1990, Schultz et al. 1992) have led others to suggest that communities associated with sulfide chimneys are unable to develop competitive biological interactions before being restructured by physical disruption (Tunnicliffe \& Juniper 1990, Van Dover 1995).

Sulfide structures formed by high-temperature venting offer particularly harsh and unstable environmental conditions, analogous to those encountered by hard substrate organisms inhabiting highly disturbed zones such as the upper intertidal (Dayton 1970, 1971, Connell 1972, Menge 1976, Lubchenco \& Menge 1978 , McClanahan 1992, Boulding \& Van Alstyne 1993, Dethier 1994, Williams 1994), boulders (Sousa 1979, Littler \& Littler 1984, McGuiness 1988) upper and shallow tide pools (Metaxas \& Scheibling 1993, Metaxas et al. 1994) and shallow and strongly exposed coral reef zones (Glynn 1976. Sheppard 1982. Wilkinson \& Evans 1989. Bythell et al. 1993, Karlson \& Hurd 1993. Rogers 1993).

On active sulfide structures, habitat conditions such as ambient temperature, fluid flow and composition can be altered by mineral precipitation, chemical or mechanical erosion and modification of fluid conduits within the mineral mass (Tunnicliffe \& Juniper 1990 , Hannington \& Juniper 1992, Juniper \& Sarrazin 1995). Organisms inhabiting a single structure can encounter conditions that range from diffuse flow at nearambient temperature $\left(\sim 2^{\circ} \mathrm{C}\right)$ to vigorously venting smoker fluids $\left(-350^{\circ} \mathrm{C}\right)$, and major habitat change can occur within species life spans (in Van Dover 1995). Large edifices often have multiple vent orifices and morphological features such as overgrowths, beehives and flanges (Tivey \& Delaney 1986, Hannington et al. 1995) that contribute to habitat heterogeneity. Beehives often cap black smokers and consist of a bulbous outer shell (mainly anhydrite) with a porous interior filled by high temperature fluid (Koski et al. 1994, Tivey 1995). Flanges are accretionary structures that grow laterally from the walls of sulfide edifices. They commonly trap pools of hot buoyant vent fluids that issue from the flange base (Delaney et al. 1992).

Several descriptive ecological models have been proposed to explain spatio-temporal distribution of hydrothermal communities. At the global scale, Juniper \& Tunnicliffe (1997) point out links between seafloor spreading rate and vent habitat characteristics that affect species diversity and other ecosystem properties. For actively-venting sulfide deposits, models of Fustec et al. (1987), Tunnicliffe \& Juniper (1990) and
Segonzac et al. (1993) describe a vertical zonation of species linked to physico-chemical gradients. Fustec et al. (1987) also describe a horizontal zonation around basalt-hosted diffuse flow vents. Only limited consideration has been given to spatial heterogeneity of hydrothermal habitats. Hannington \& Juniper (1992) propose that vertical physico-chemical gradients predominate in the control of organism distribution on large sulfide structures but acknowledge patchiness as an element of spatial distribution of some hydrothermal communities. Faunal cartography by Chevaldonné \& Jollivet (1993) clearly illustrates spatial heterogeneity of alvinellid polychaete distribution on black smoker chimneys at $13^{\circ} \mathrm{N}$ (East Pacific Rise).

Time-series observations of actively-venting sulfide edifices are few but most indicate notable environmental changes (in Tunnicliffe \& Juniper 1990, Juniper \& Sarrazin 1995). In this first of a series of planned observatory studies of the evolution of hydrothermal communities and their habitat, video imagery was used to study faunal community distribution and changes in relation to the geological evolution of an active sulfide structure over a period of $4 \mathrm{yr}$. Video imagery provides spatially continuous information on biological community composition and substratum and flow features at the scale of individual hydrothermal sites (Grehan \& Juniper 1996). This paper develops a dynamic ecological model that considers physico-chemical heterogeneity and the role of perturbations in determining community distribution patterns over an entire sulfide structure including high- and low-temperature habitats.

\section{MATERIALS AND METHODS}

Study site. The Endeavour Segment of the Juan de Fuca Ridge is located 350 to $400 \mathrm{~km}$ off the coast of British Columbia and Washington (Fig 1A). This area has been designated by the US RIDGE program as the primary site for seafloor observatory studies of the interaction of hydrothermal and biological processes (Delaney \& Hildebrand 1993, Juniper et al. 1994). Three hydrothermal vent fields (Fig. 1B) along the axis of the volcanic high of this ridge segment have been intensively investigated (Merge Group 1994, Delaney et al. 1989, 1991, 1992, Thomson et al. 1992, Robigou et al. 1993, Lilley et al. 1995, D. S. Kelley et al. unpubl.). The Main Endeavour vent Field (MEF) located near $47^{\circ} 57^{\prime} \mathrm{N}$ lies on the axial valley floor at a depth of 2200 m (Tivey \& Delaney 1986). In this field, active sulfide edifices are distributed along a $020^{\circ}$ trending fissured zone parallel to the west wall of the valley (Delaney et al. 1992). These high-relief structures stand almost vertically on the surrounding basaltic floor 

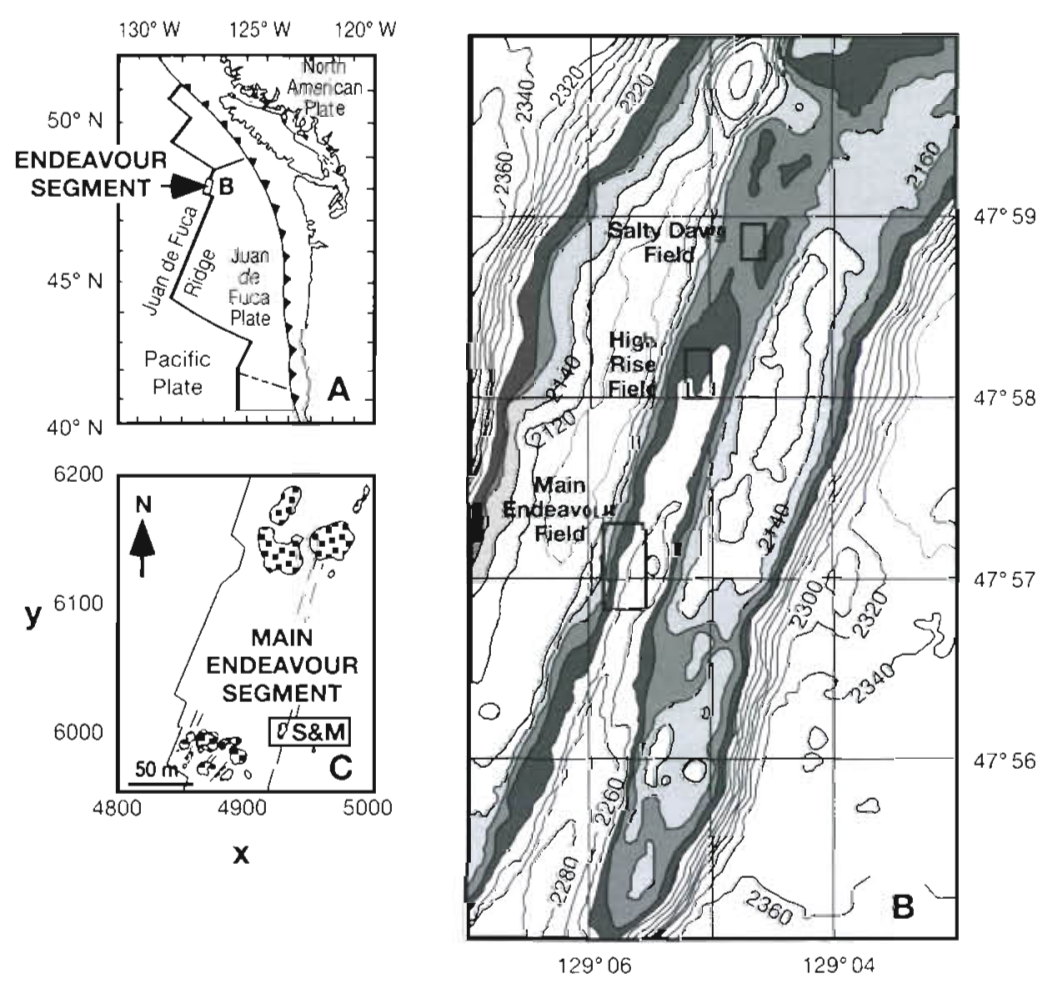

Fig. 1 (A) Location of the Endeavour Segment, Juan de Fuca Ridge in the northeast Pacific Ocean. (B) Seaßeam bathymetry of the central part of the Endeavour Segment. Boxes represent mapped hydrothermal vent fields located on the axial valley floor (C) Simplified geological map of the Main Endeavour Field modified from Delaney et al. (1992). South of $Y=6000 \mathrm{~m}$, the map has been upgraded using 1995 Alvin dive data. The S\&M (abbreviation for Smoke and Mirrors) sulfide structure $(X=4920$ and $Y=6000)$ is located on the edge of a fault scarp in the centre of the active hydrothermal vent field

and vent high-temperature fluids channeled to their tops where most of the black smoker activity occurs. Many of these sulfide structures are characterized by multiple tiers of horizontal ledges or flanges extending laterally from the sides of the vertical walls (Delaney et al. 1992, Hannington et al. 1995).

The focus of this temporal study is an actively venting, sulfide-sulfate-silica structure named S\&M (abbreviation for Smoke and Mirrors) for the presence of vigorous black smokers and flanges with their reflecting pools of trapped hydrothermal fluid (Delaney et al. 1992). S\&M, a complex edifice located in the center of the MEF (Fig. 1C), is roughly $10 \mathrm{~m}$ long and $5 \mathrm{~m}$ wide and elongated parallel to the $020^{\circ}$ trend of the axial valley. Perched on an east-facing scarp typical of the fractured valley floor of the vent field (Delaney et al. 1992), S\&M is composed of 3 lobes that partially overhang the fault scarp. From north to south, we refer to the Dog Head complex approximately $5 \mathrm{~m}$ high, the $8 \mathrm{~m}$ high Northern Cluster and the Southern Cluster about $10 \mathrm{~m}$ in height (see Fig. 2). A. $1 \mathrm{~m}$ high inactive zone at the base leads directly into an active diffuse flow zone varying in height from 2 to $4 \mathrm{~m}$ on Dog Head, to 5 to $7 \mathrm{~m}$ on Northern Cluster and about $9 \mathrm{~m}$ on Southern Cluster. $S \& M$ is a relatively small edifice (estimated volume of $500 \mathrm{~m}^{3}$ ) compared to other venting sulfide structures described in this vent field (Delaney et al. 1992). Venting temperatures measured on black smokers over the years range from 329 to $369^{\circ} \mathrm{C}(\mathrm{n}=7)$ but show no systematic variation over time (Butterfield et al. 1994). The morphology of this sulfide edifice is slightly different from the typical Endeavour-type morphology described by Delaney et al. (1992) and Robigou et al. (1993) for the vent fields along this ridge segment and will be discussed later in this paper.

Imagery. Video imagery was acquired during dive programs in the MEF using 3 different diving platforms: the remotelyoperated vehicles (ROVs) Jason and ROPOS, and the manned submersible Alvin. Jason (July) and Alvin (September) dives were conducted in 1991, followed by a single ROPOS dive series in 1994 (July), and in 1995 by separate ROPOS (July) and Alvin (September) programs. Data from 21 different dives that visited $\mathrm{S} \& \mathrm{M}-3$ in 1991,7 in 1994 and 11 in 1995 - were analyzed.

During Alvin and ROPOS dives, lowlight black and white Silicon Intensified Targeting (SIT) imagery was first collected at 2 to $5 \mathrm{~m}$ from the structure for a global overview. This is an essential step in defining the general orientation of major features and the morphology of the entire structure. Alvin SIT camera imagery from 1991 combined with Alvin high-precision in-hull navigation served to produce the base map on which geology and biology were plotted (Figs. 2 \& 3). Fine-scale biological and geological information was acquired in color imaging transects at different elevations on the sulfide edifice with the submersible or ROV facing the structure. Vertical transects (bottom to top) at selected sites, with the imaging platforms maintained at approximately $1 \mathrm{~m}$ from the edifice surface, complete the detailed surveys. In 1995, zoom lenses were added to the ROPOS and Alvin 3-CCD color cameras. Zoom level was held constant (wide open) for all transects to ensure that images would be of comparable scale. Recognizable natural or man made features near transect lines enabled imaging transects to be repeated over different years. In order to orient reconstruction of complex vertical features, it was essential that successive 


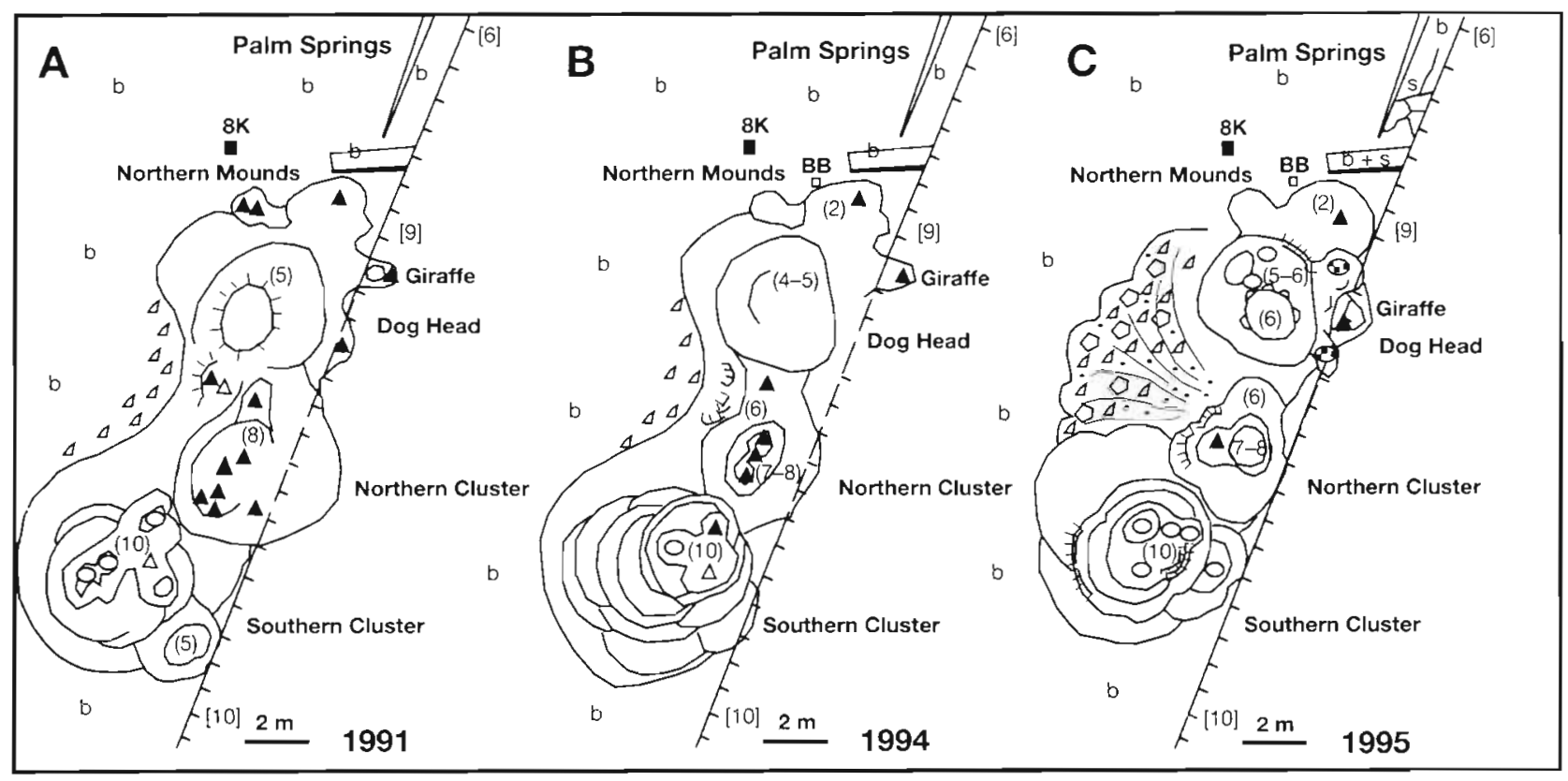

Legend $b$ Basaltic lobate flows

s Sulfide deposition on basaltic floor

A Black smoker

$\exists$ Sulfide flange with pool

Beehive

$\triangle$ Sulfide talus
8K Marker (1.5 m high)

${ }_{\square}^{\text {BB }}$ Marker

(8) Elevation of sulfide edifice from basaltic floor on western side of fault (in meters)

[8] Elevation of fault scarp from basaltic floor on eastern side of fault (in meters)

L Fault

- Beehive covered by Paralvinella sulfincola

Do. Sulfide 'landslide'

Fig. 2. Geological maps of S\&M for the 3 years of the study. Structure is composed of 3 principal lobes, from north to south, the Dog Head complex, the Northern Cluster and the Southern Cluster: (A) 1991 (September); (B) 1994 (July); (C) 1995 (September). For 1995, note the landslide fan at the base of the western face of S\&M and the appearance of small sulfide deposits (s) on the basaltic floor at the northern end of the edifice

images showed identifiable features such as chimneys, flanges or beehives. This requirement was respected whenever possible during image collection or used as an image selection criterion for cartography.

Geological and biological mapping. A geological base map (plan view; Fig. 2A) and a vertical rendering base map of the west face of $S \& M$ were prepared from the 1991 Jason and Alvin imagery (Fig. 3A). The west face was chosen for detailed faunal studies because it offered a large and accessible area representative of the full vertical and horizontal extent of the structure. Working from a vertical rendering base map helped alleviate complications in reconstructing the west face from imagery obtained from 3 different submersibles with different cameras and many viewing angles. Imagery from the 1994 and 1995 ROPOS dives and the Alvin dives in September 1995 was then used to update the 1991 base maps to include changes in morphology and hydrothermal venting (Fig. 3B, C). Basemap updates for 1994 and 1995 used submersible depth and position data and recognizable geological features for registration to the 1991 base maps (Fig. 3). The basic mapping technique is described in Delaney et al. (1992). Absolute position information for Fig. 2 is accurate to $\pm 1.5 \mathrm{~m}$ for $x, y$ coordinates and $\pm 2 \mathrm{~m}$ for elevations. All elevations reported on the maps are in meters above the basaltic seafloor on which S\&M stands

Faunal distribution maps of the west face of the structure (Fig. 3) were constructed from detailed observations of video images and compiled on the vertical renderings for each year of the study. Visually distinct faunal communities were mapped from video transects by repeatedly reviewing recorded video and sketching faunal distribution around recognizable morphological features on the base maps. A video editing suite was used to control tape movement during all mapping procedures (Grehan \& Juniper 1996). In a first step, contours of faunal patches were drawn from frozen video frames. Next, sections of draft maps corresponding to major structural features (Fig 2) were corrected by viewing video sequences frame by frame 

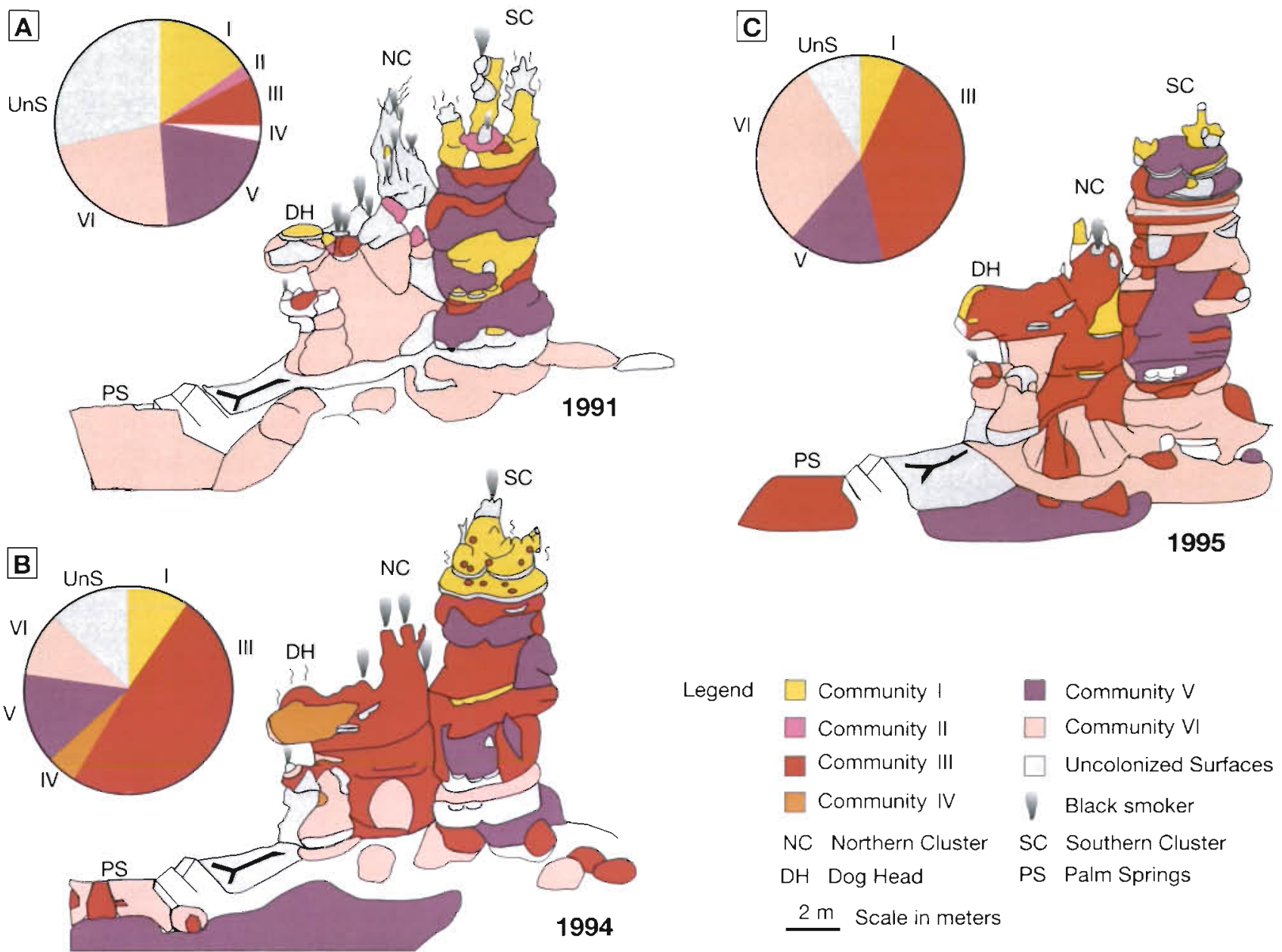

Fig. 3. Community spatio-temporal distribution maps of the west face of S\&M: (A) 1991 (July); (B) 1994 (July); (C) 1995 (July). White zones represent unmapped areas. Pie diagrams summarize relative distribution of communities and uncolonized surfaces on the sulfide edifice for the different years

and in continuous play. Both horizontal and vertical transects were examined during this revision procedure to reduce error related to viewing angle (Grehan \& Juniper 1996).

Close-up photographs and video imagery were used to identify 6 faunal communities that are slightly different from previously described Juan de Fuca sulfide structure faunas (Tunnicliffe \& Juniper 1990, Hannington \& Juniper 1992). We use the term communities here to describe species assemblages that recur under particular habitat conditions. Arguably, the term assemblage might be more appropriate given the lack of knowledge of interactions between species. Since these communities were identified only from imagery, distribution maps convey no information regarding meiofauna or species within the 'understory' of tube worm aggregations.

Observations of the morphology of the sulfide edifice and the distribution of hydrothermal venting on the structure were also compiled on the geologic maps
(Fig. 2) and on the vertical renderings of the west face (Figs. 3 \& 5), to analyze relationships between biology, geology and fluid flow through time. The distribution of visible shimmering flow of hydrothermal fluids on the west face of S\&M was mapped using the same video records and procedure described above for faunal mapping.

Surface analysis. Quantitative 2-D surface analyses for each community type on the west face of S\&M were performed on hand-digitized maps for the 3 years using IPLab Spectrum image analysis software (Grehan \& Juniper 1996). Each community patch or bare surface was digitized and analyzed 3 times, to reduce error resulting from on-screen tracing. Total mapped area occupied by each distinct community or by uncolonized surfaces was then calculated in pixels as the average of 3 separate determinations. Surfaces were then transformed into square meters relative to the 2-D surface of the west face of S\&M (see Table 1). Parallel 
laser points (10 cm separation) present in ROPOS video imagery were used to scale the maps for areal calculations. This 2-D reconstruction does not take surface relief or thickness of faunal coverage into account, but does reveal major temporal changes of the morphology of the deposit and of the space occupied by different communities. The total number of patches occupied by distinct communities and by uncolonized surfaces was estimated for the 3 years of the study (see Table 2). A patch is defined as 'an enclosed surface' that was occupied by a same type of community or was uncolonized.

Temporal variation analysis. A quantitative data base for analysis of the temporal evolution of communities, surfaces (Fig. 3) and flow patterns (Fig. 5) on the west face of S\&M was developed from an electronically-generated grid with a $25 \times 25 \mathrm{~cm}$ mesh size (Fig. 4). The grid was overlain on digitized maps of faunal distribution (Fig. 3) and visible flow features (Fig. 5) by registering to a reference point visible on all base maps (Grehan \& Juniper 1996). This point was fixed to GPS coordinates during the 1995 Alvin dive series. From this reference origin, every $0.0625 \mathrm{~m}^{2} \mathrm{grid}$ square was assigned individua! Y/Z coordinates. Each of the approximately 1600 grid squares was examined on screen and assigned a surface attribute (S) according to dominant community type or the presence of a bare surface (Fig. 3), and the presence/absence of visible shimmering flow (Fig. 5). The Y/S/Z matrices were then compared between the 2 time intervals (1991-1994 and 1994-1995) to determine the frequency of changes in $S$ relative to $Y$ and $Z$, and to explore trends in community change. Community change is first represented graphically as the frequency at which squares of a given surface attribute remained unchanged or were altered by acquiring one of 6 possible attributes (Fig. 9). The Y/S/Z data base was also used to construct transition probability matrices, used in the description of successional processes among identified communities in a given ecosystem (Legendre \& Legendre 1983). Finally, the colonization of shimmering surfaces by different faunal communi-

Fig. 4. Example of electronically generated grid superimposed on faunal maps of the western face of the S\&M sulfide edifice (1991). Faunal community changes were determined by comparing individual grid squares through time. Grids also served to identify communities occupying shimmering surfaces. The grid has 2 axes: a $Z$ axis corresponding to the depth (Alvin depth) in meters from the surface and a $Y$ axis in horizontal meters relative to navigated origin visible in imagery ( $X: 4917 \mathrm{~m}$ and $\mathrm{Y}: 6006 \mathrm{~m}$ in Fig. 1C) ties was evaluated from a pooled data set (for all 3 years of the study) of grid squares where shimmering flow was present (Fig. 5D).

Temperature. Fluid temperatures on S\&M were measured by temperature probes during the 5 dive series. Sampling was not systematic between years, so many temperature data are not replicated. Mean temperature data for the different communities make no distinction as to where measurements were made relative to the surface or interior of organism clumps. The temperature data serve as an indication of the intensity of hydrothermal flow occurring within each of the described communities. In 1995, chemical scans were also taken among communities using the SUAVE in situ chemical analyzer (Massoth et al. 1989, Sarrazin et al. 1993). Detailed community composition and habitat physico-chemical characteristics will be presented in future papers (Sarrazin et al. unpubl.).

\section{RESULTS}

\section{Structural modifications}

Chimney growth. The general shape of the S\&M structure did not change appreciably over the 1991-1995 time interval, but many local morphological and volumetric variations were documented, primarily related to sulfide accretion at the top of the structure and in the vicinity of active black smokers (Fig. 3). Estimated total chimney surface (west side) increased by

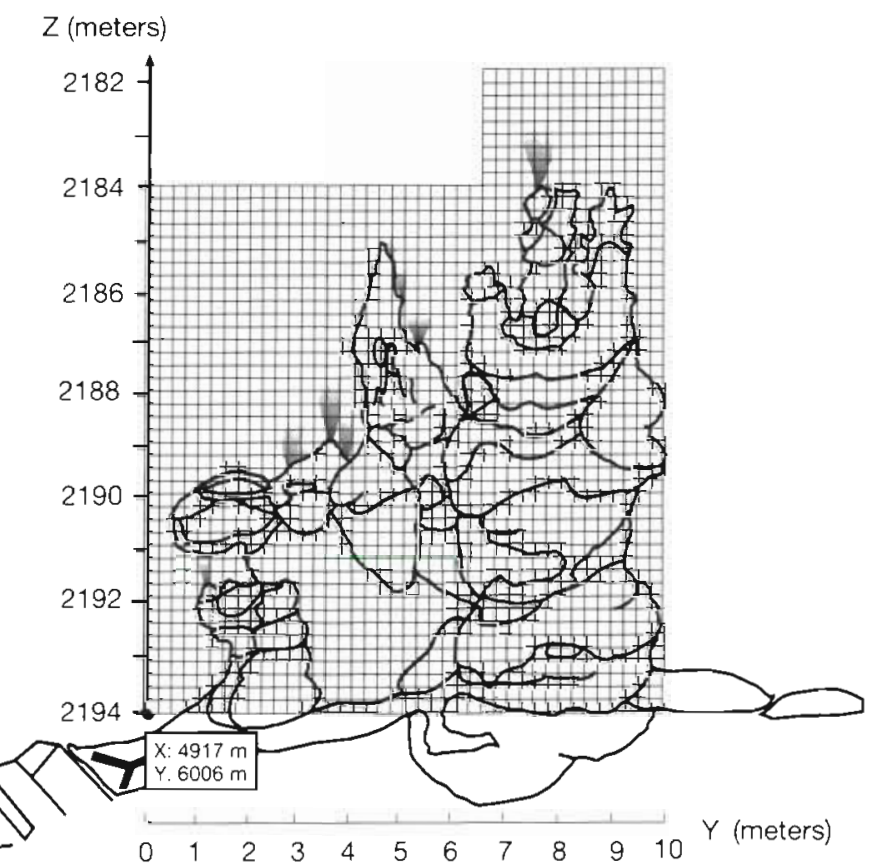


Table 1. Occupation of S\&M edifice surfaces (west face) by different communities in 3 separate years. Surfaces were calculated from total surface occupied by a community in relation to total mapped chimney surface. Surfaces are given in $\mathrm{m}^{2}$ as determined from surfaces measurements in digitized 2-D maps

\begin{tabular}{|lrrr|}
\hline & 1991 & 1994 & 1995 \\
\hline S\&M west side surface analysis & & & \\
Total surface west face $\left(\mathrm{m}^{2}\right)$ & 80.9 & 88.5 & 89.9 \\
Total mapped surface $\left(\mathrm{m}^{2}\right)$ & 79.1 & 83.5 & 87.3 \\
Mapped/total surface $(\%)$ & 98 & 94 & 97 \\
& & & \\
Area occupied on mapped surface $\left(\mathrm{m}^{2}\right)$ & & \\
Community I & 10.9 & 8.1 & 4.2 \\
Community II & 1.6 & 0.0 & 0.0 \\
Community III & 6.3 & 40.6 & 31.3 \\
Community IV & 2.1 & 3.7 & 0.0 \\
Community V & 17.0 & 12.4 & 12.9 \\
Community VI & 20.7 & 8.5 & 31.3 \\
Total colonized surfaces & 58.6 & 73.3 & 79.7 \\
Total uncolonized surfaces & 20.5 & 10.2 & 7.6 \\
\hline
\end{tabular}

$10 \%$ between 1991 and 1995 (Table 1). Most of this hydrothermal precipitate accumulation occurred between 1991. and 1994 (9.3\% increase). Slowing of growth between 1994 and 1995 corresponds with an overall. reduction of high-temperature vent sites and an increase in diffuse venting surfaces (Fig. 5B, C) Active chimney growth creates new colonization surfaces for organisms. For example, the area named 'Giraffe' grew from $2 \mathrm{~m}$ to $4 \mathrm{~m}$ in height between 1991 and 1995 (Fig. 2A, C). The 'Dog Head' complex increased by $1 \mathrm{~m}$ in height in the same time interval (Fig. 2A, C).

Structural failure. Catastrophic structural failures were fairly common. In 1991, the Northern Cluster chimney, $16 \mathrm{~m}$ above bottom when first observed, repeatedly collapsed and reformed during the July dive series, finally stabilizing near $8 \mathrm{~m}$ in September (Fig. 2A). The height of Southern Cluster changed little over 4 yr (Fig. 2), but newly formed spires were always observed on top, suggesting a similar cycle of destruction and regrowth, but at a smaller scale. Erosion of the growing sulfide deposit by 'structural collapse' was also observed. An apparent slide observed on Northern Cluster chimney in 1991 resulted in the partial defaunation of a large surface (community VI, Fig. 3A). In 1995, a substantial talus fan appeared on the western side (Figs. 2C \& 3C) coincident with a reduction in volume of the upper Northern Cluster spire. While total uncolonized surfaces decreased from $20.5 \mathrm{~m}^{2}$ in 1991 to $7.6 \mathrm{~m}^{2}$ in 1995 (Table 1), numerous bare patches both mapped and unmapped indicate many more small scale perturbations during this time interval (Table 2). Some may be related to maneuvering of the ROV in 1994.
Table 2. Patch abundance of different communities and uncolonized surfaces for 3 years (S\&M west side)

\begin{tabular}{|lccc|}
\hline & \multicolumn{3}{c|}{ No. of patches } \\
& 1991 & 1994 & 1995 \\
\hline Community I & 6 & 3 & 9 \\
Community II & 4 & 0 & 0 \\
Community III & 7 & 5 & 9 \\
Community IV & 2 & 2 & 0 \\
Community V & 2 & 3 & 4 \\
Community VI & 1 & 6 & 10 \\
Total uncolonized surfaces & 14 & 16 & 18 \\
Total no. of patches & 36 & 35 & 50 \\
& & & \\
\hline
\end{tabular}

\section{Documented changes in flow types}

Defocusing of flow. At the beginning of the study (1991), S\&M was composed of 13 vigorously-venting black smokers, numerous beehives and 1 overflowing flange pool (Fig. 5A) distributed mostly on the summits of the Northern Cluster and Dog Head complexes (Fig. 2A). Focused discharge points decreased to 7 black smokers in 1994 and 3 in 1995 (Figs. 2 \& 5B, C) The Dog Head flange pool disappeared between 1991 and 1994 (Fig. 5A, B). Concurrent with the decrease in smoker numbers, there was an overall increase in the total area of shimmering water emissions, primarily as a result of the appearance of new shimmering surfaces on the Northern Cluster complex (Fig. 5). There is a negative correlation ( $\mathrm{r}=-0.83$, not significant) between black smoker numbers and total shimmering surfaces for the entire sulfide structure (Fig. 6). Southern Cluster stayed mostly active through diffuse flow during the 4 yi interval. It had no active black smokers in September 1995 (Fig 2C).

Flow focusing. In 1995, 2 new overflowing flanges with grey plumes were observed on the Southern Cluster base and another on the Dog Head complex (Fig. 5C), and new active beehives had appeared on the southern part of Northern Cluster and on top of Southern Cluster (Fig. 2C). The accidental destruction of a clogged spire during ROV operations at the top of S\&M in July 1995 led to the creation of 2 black smokers and new spires. Initial spire growth after the perturbation was rapid, up to approximately $10 \mathrm{~cm} \mathrm{~d}^{-1}$ Two months later, during the 1995 Alvin cruise, the smokers had disappeared, several new beehives were visible and the new spires had stabilized at $80 \mathrm{~cm}$ or less in height (Fig. 2C).

Activation. New hydrothermal flow through basalts appeared in many small areas at the base of S\&M between 1991 and 1995. In 1995, shimmering surfaces were more numerous on adjacent basalts than in 1991 (Fig. 5). The most noticeable event was the creation of 


\begin{tabular}{|l|c|c|c|}
\hline & 1991 & 1994 & 1995 \\
\cline { 2 - 4 } Black smokers & 13 & 7 & 3 \\
P Active flange pools & 1 & 0 & 3 \\
Shimmering surfaces $\left(\mathrm{m}^{2}\right)$ & 7.2 & 7.5 & 12.6 \\
\hline
\end{tabular}

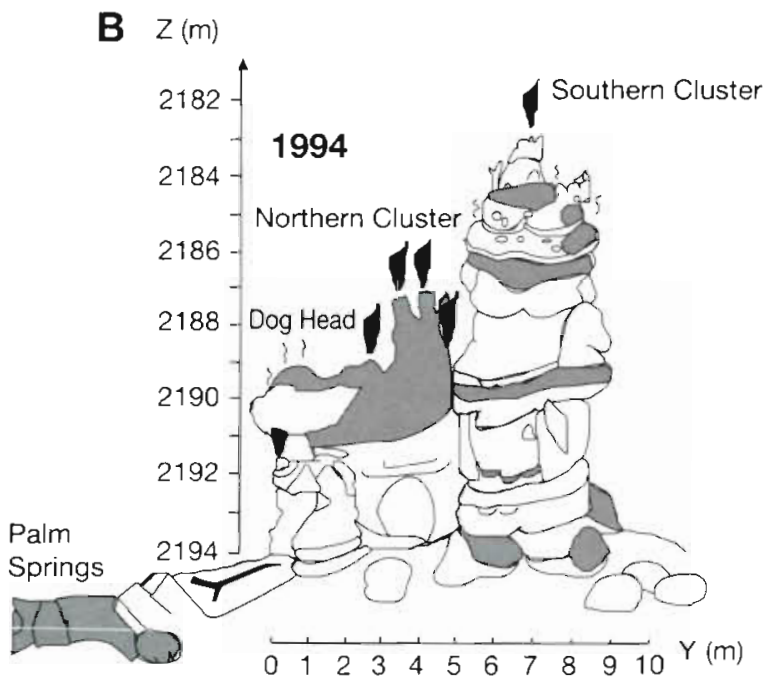

D

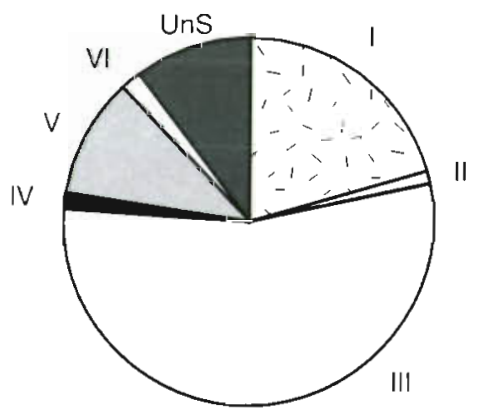

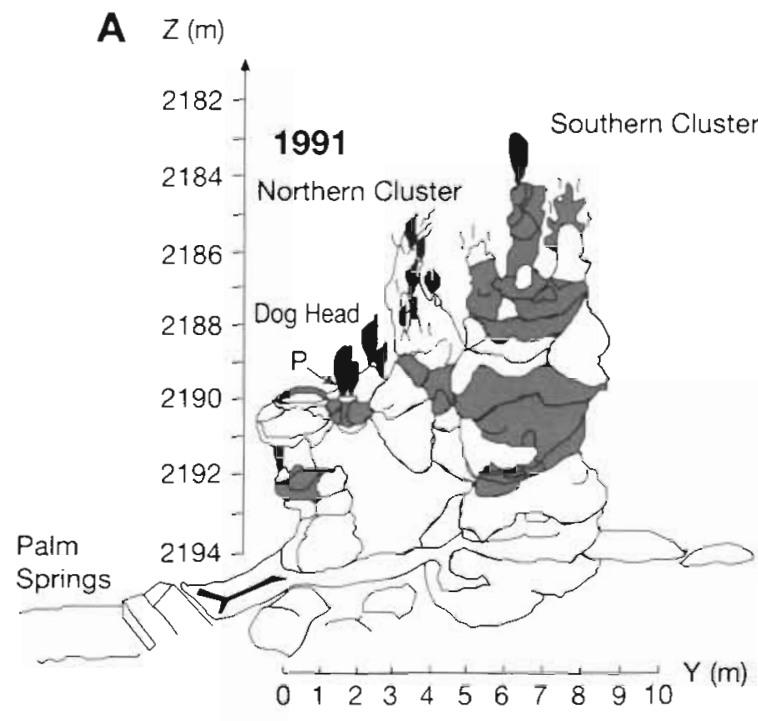

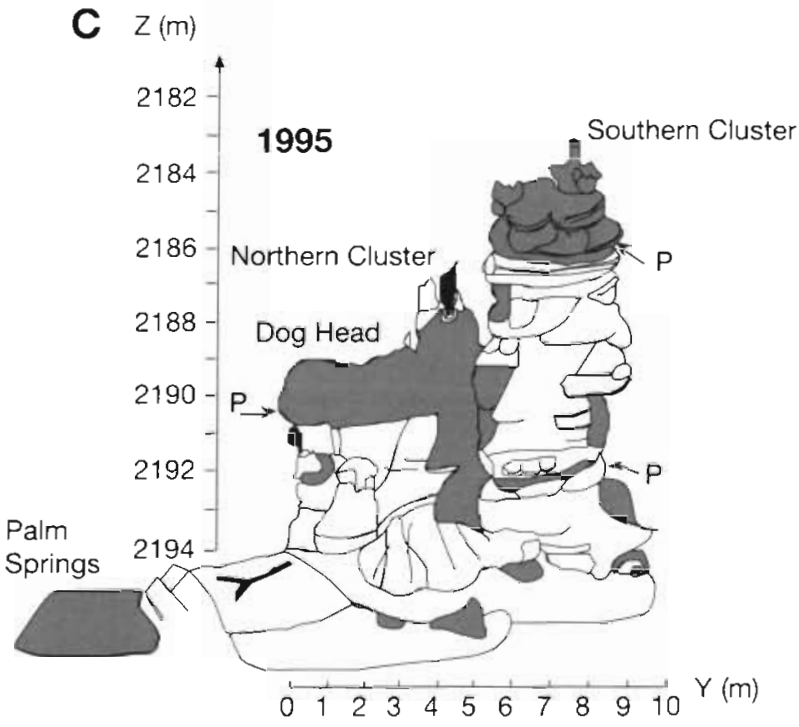

Fig. 5. Distribution of shimmering surfaces, smokers and active flange pools on the west face of S\&M for the 3 years of the study: (A) 1991; (B) 1994; (C) 1995. Table summarizes visible venting features. Giraffe and Dog Head smokers on the east side of S\&M (see Fig. 2) are not visible from this angle. (D) Pie diagram shows the percentage of the total area of shimmering flow (sum 1991. 1994 and 1995) occupied by the different faunal communities (I to VI) or uncolonized surfaces (UnS)

an extensive diffuse-flow environment (Palm Springs) on the basaltic floor at the northern end of the structure (Figs. 2, 3 \& 5). The activation of this site apparently began prior to July 1994, when patchy colonization of shimmering surfaces by palm worms Paralvinella palmiformis and limpets Lepetodrilus fucensis was first observed. The active area was completely colonized in 1995 (Fig. 3C). Further, fissures north of the tilted basaltic block at the edge of the fault showed new mineral deposition in 1995 (Fig. 2C). Sulfides were seen protruding over the fissure suggesting new sulfide accumulation north of the structure. In 1995, local flux increases at the base of both Southern and Northern Clusters apparently created new active flanges (Fig. 5C).

\section{S\&M communities}

Community composition. Each of the 6 identified faunal communities (Fig. 7) appears to have distinct habitat characteristics in terms of physico-chemical conditions (Table 3). Four communities contain vestimentifera (Ridgeia piscesae Jones in Southward et al. 1995) whose tubes serve as substrata for other 


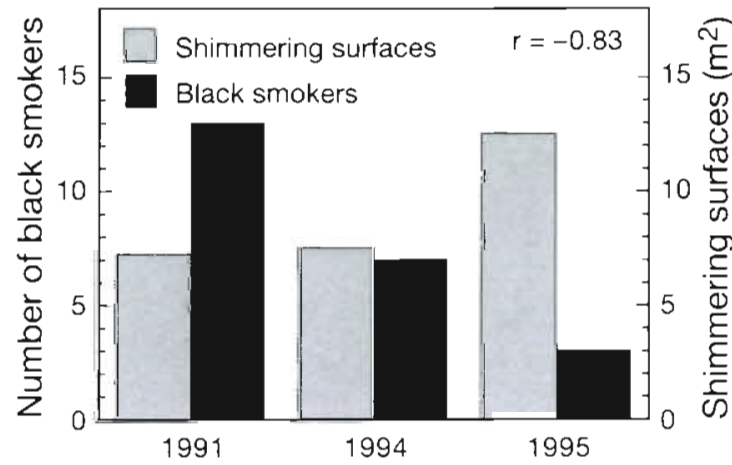

Fig. 6. Relationship of black smoker abundance to total shimmering surfaces on S\&M for the 3 years of the study. Correlation coefficient ( $r$ ) is for smoker numbers vs total shimmering surfaces $\left(\mathrm{m}^{2}\right)$

species, and are differentiated by worm tube lengths and relative species abundances (Fig. 7C-F). Two communities contain only alvinellid polychaetes (Paralvinella sulfincola and $P$. palmiformis) (Fig. $7 \mathrm{~A}, \mathrm{~B}$ ). Groundtruthing of these communities for their total composition and relative abundance of species will be described in detail in a future manuscript (Sarrazin et al. unpubl.).

Community I is exclusively composed of the sulfide worm Paralvinella sulfincola (Polychaeta: Annelida). These monospecific populations were restricted to particular low-flow, high-temperature environments such as newly-formed sulfide chimney summits, flange tops and flange pool surroundings (Table 3). The mean temperature measured in this community was $42.3^{\circ} \mathrm{C}$ $(n=15)$. Low abundances of sulfide worms were also recorded within other communities such as community $\mathrm{V}$.

Community II is an assemblage of Paralvinella palmiformis (Polychaeta: Annelida) and Paralvinella sulfincola, where the latter irregularly colonized the background substratum and $P$. palmiformis was dispersed in small aggregations (patches) on marcasite outgrowths. It occurred in medium to high temperature, diffuse flow environments where weak to high volume shimmering flows were irregularly distributed (Table 3). Temperature conditions were not measured for this community on S\&M. On another structure at Endeavour Segment, where community II occupied the surface of a flange, temperature varied from $36.8^{\circ} \mathrm{C}(\mathrm{n}=18)$ for the entire flange surface to $17.7^{\circ} \mathrm{C}$ ( $\mathrm{n}=$ $6)$ in palm worm aggregations on raised surface outgrowths (Juniper unpubl. data). This community, mapped only in 1991 on S\&M, was probably present to a lesser extent in 1994 and 1995 but patches of $P$. palmiformis were too rare to permit mapping of community II in areas dominated by community $\mathrm{I}$.

Community III is defined by dense patches of Paralvinella palmiformis against a background of numerically dominant limpets (Lepetodrilus fucensis: Archaeogastropoda: Mollusca) and snails (Provanna variabilis: Mesogastropoda: Mollusca and Depressigyra globulus: Archaeogastropoda: Mollusca). Small tube worms are occasionally present. Bacteria-coated polynoids (Lepidonotopodium piscesae: Polychaeta: Annelida) are usually abundant. In video imagery, community III was white-grey with clusters of red palm worm gills. Community III appeared to prefer high flow and medium temperature diffuse-flow habitats either on sulfide chimney surfaces or on the basaltic seafloor (Table 3 ). Mean measured temperature around $P$. palmiformis was $17.9^{\circ} \mathrm{C}(\mathrm{n}=48)$.

Community IV is composed of 1 limpet (Lepetodrilus fucensis) and 2 snail species (Provanna variabilis and Depressigyra globulus) which densely cover small vestimentiferan tubes (Ridgeia piscesae: Vestimentifera: Pogonophora). This assemblage of organisms gave the community a fine rubbled (granular) texture and grey coloration. It appeared to be associated with mediumflow, low-temperature habitats although no temperature measurements were made directly in this commu-

Table 3. Community descriptions and visible habitat characteristics for S\&M chimney complex (Juan de Fuca Ridge). Organisms listed are observable in video imagery. Presence or absence of other species within the community is not implied --: absent, + : present, () occasionally present. For species presence only: + low abundance, ++ : medium abundance, +++ : high abundance. Temperature low: 0 to $10^{\circ} \mathrm{C}$, medium: 10 to $20^{\circ} \mathrm{C}$, high: above $20^{\circ} \mathrm{C}$

\begin{tabular}{|c|c|c|c|c|c|c|}
\hline & \multicolumn{6}{|c|}{ Community } \\
\hline & I & II & III & IV & V & VI \\
\hline \multicolumn{7}{|l|}{ Organisms } \\
\hline Ridgeia piscesae & - & - & $(+)$ & +++ & +++ & ++ \\
\hline Paralvinella sulfincola & +++ & +++ & - & - & + & - \\
\hline Paralvinella palmiformis & - & +++ & +++ & - & ++ & - \\
\hline Gastropods & - & - & +++ & +++ & +++ & + \\
\hline Bacterial mats & - & - & - & - & $(++)$ & $(++)$ \\
\hline Polynoids & $(+)$ & $(+)$ & +++ & $(+)$ & + & + \\
\hline Pycnogonids & - & - & + & $(+)$ & + & + \\
\hline Protozoans & - & - & - & - & $(+)$ & $(++)$ \\
\hline \multicolumn{7}{|l|}{ Habitat characteristics } \\
\hline \multicolumn{7}{|l|}{ Flow features } \\
\hline Visible shimmering flow & + & + & + & $(+)$ & $(+)$ & - \\
\hline Relative temperature & high & $\begin{array}{l}\text { medium- } \\
\text { high }\end{array}$ & medium & low & low & low \\
\hline \multicolumn{7}{|l|}{ Substratum } \\
\hline Sulfide & + & + & + & + & + & + \\
\hline Basalt & - & - & + & + & + & + \\
\hline
\end{tabular}



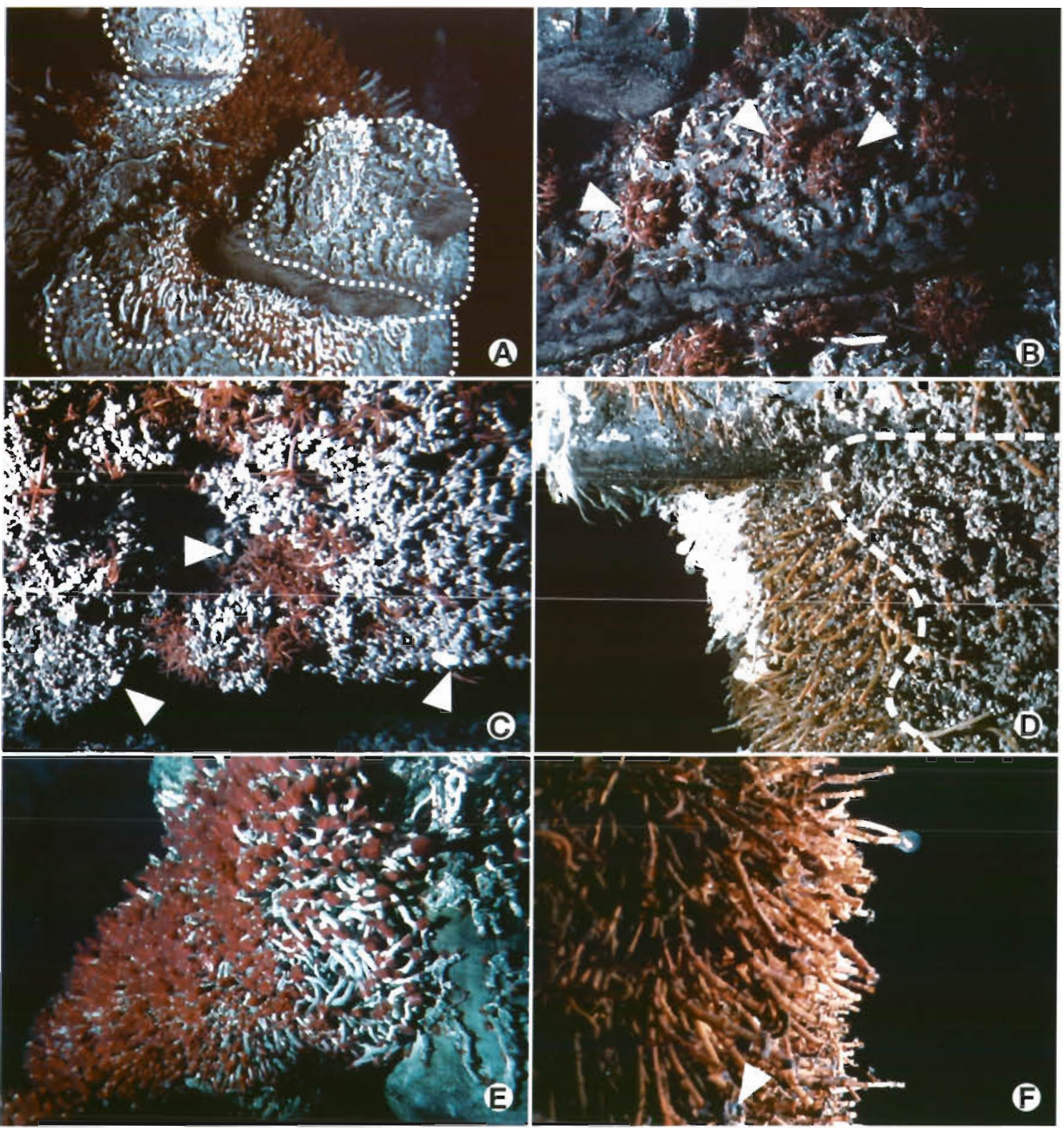

Fig. 7. Identified faunal communities on S\&M. (A) Monospecitic community I (outlined areas): exclusively composed of sulfide worms, Paralvinella sulfincola. (B) Community II: assemblage of the palm worm Paralvinella palmiformis and the sulfide worm $P$. sulfincola. The latter irregularly colonize the background substratum while $P$. palmiformis is dispersed in small aggregatıons on marcasite outgrowths (arrows). (C) Community III: dense patches of $P$. palmiformis against a background of numerically dominant limpets Lepetodrilus furensıs and sndils Provanna variabilis and Depressigyra globulus. Small tube worms are occasionally present (not visible here). Bacteria-coated polynoid polychaetes Lepidonotopodium piscesae are usually abundant (arrows). (D) Community IV (outlined on right): Limpets $L$. fucensis and 2 species of snails D. globulus and $P$. variabilis densely covering small vestumentiferan Ridgeid piscesae tubes. Shown here merging into community $V$ (left of outlined area). Communities III and IV mainly distinguished by the visible presence (III) or absence (IV) of $P$ palmuformis. (E) Community V: dominated by tube worms, limpets and snails. Long vestimentiferans $R$. piscesae give this community ats appearance since other species are mainly in the understory. Where shimmering flow is abundant $(E)$, community $V$ is dominated by large diameter tube worms with well-developed gills and unusually large palm worms. In lower flow situations (D), community $V$ tube worms are narrower and gastropods are much more abundant. (F) Community VI: apparently dead or unhealthy brown-colored tube worms. Colonization

of tube worms by organisms such as filamentous white bacteria, blue colonial ciliates (arrow) or detritivores is common 
nity (Table 3). Communities III and IV were mainly distinguished by the visible presence (III) or absence (IV) of Paralvinella palmiformis.

Community $\mathrm{V}$ is usually the most species rich $(16$ species, Sarrazin et al. unpubl.) and is numerically dominated by vestimentifera (Ridgeia piscesae), limpets (Lepetodrilus fucensis) and snails (Provanna variabilis and Depressigyra globulus). Long tube worms gave this community its appearance since other species were mainly in the understory. Community $V$ was observed in diffuse-flow environments either on active chimneys walls or on basaltic substrata (Table 3 ). Mean measured temperature for $R$. piscesae distribution is $6.6^{\circ} \mathrm{C}(n=57)$. Vestimentiferan growth rates in $S \& M$ area varied from none (on the basaltic seafloor, Tunnicliffe, pers. comm.) to more than $30 \mathrm{~cm} \mathrm{yr}^{-1}$ (top Southern Cluster 1995, Sarrazin et al. unpubl.).

Community VI is characterized by the presence of apparently dead or unhealthy brown-colored tube worms. This community appeared to be associated with low-flow, low-temperature habitat or with hydrothermally inactive areas (Table 3). Colonization of tube worms by organisms such as filamentous white bacteria, protozoans or detritivores is common. Bacteria appeared to colonize tubes exposed to low-temperature emissions $\left[ \pm 9.9^{\circ} \mathrm{C}(n=14)\right.$, Sarrazin et al. unpubl.] Pycnogonids (Pycnogonida: Arthropoda) were occasionally abundant

Species richness. The total colonized surface on S\&M increased from $58.6 \mathrm{~m}^{2}$ in 1991 to $79.7 \mathrm{~m}^{2}$ in 1995 (Table 1). Between 1991 and 1994, visible (in video and still photos) species richness increased with the addition of 2 species: a blue mat-forming folliculined protozoan (Small \& Gross 1985) and a substantial population of large yellow snails (Buccinum viridum: Neogastropoda: Gastropoda). The buccinid was present tens of meters north of S\&M in 1988 (Tunnicliffe pers. comm.). Little information is available on these organisms and their habitat preferences.

Other species associated with the S\&M environment. There were more predatory crabs (Macroregonia macrochira: Decapoda: Arthropoda) around S\&M in 1994-1995 than in 1991. These crabs are generally attracted to food sources such as dying tube worm clumps, where sulfide flux is minimal or absent. Tunnicliffe (1990) describes this opportunistic behavior after sampling a vent around Axial Seamount (Juan de Fuca). Other predators such as galatheid crabs (Munidopsis alvisca: Decapoda: Arthropoda) and fishes (Pachycara gymnium: Perciforma: Chordata) were also observed around the active structure. Non-vent abyssal species were rare in this area, but some asteroids, nudibranchs and bryozoans colonized the basaltic valley floor, inactive sulfide deposits and even vestimentiferan tubes

\section{Community spatio-temporal distribution}

Community maps for the west face of S\&M portray a great deal of spatial patchiness that varied significantly between years (Fig. 3). The total number of identifiable patches formed by the different communities increased from 36 in 1991 to 50 in 1995 (Table 2). Community VI showed the greatest overall increase in number of patches between 1991 and 1995 (Table 2). Sharp increases in the abundance of community I and III patches between 1994 and 1995 also contributed substantially to the 1995 heterogeneity peak. Two communities (I and III) decreased their number of patches during the 1991-1994 interval (Table 2). The number of patches did not reflect total surface area occupied. For example, although community VI patch number increased between 1991 and 1994, the total surface occupied by this community decreased (Tables $1 \& 2$ ).

Occupation of S\&M surfaces by particular communities varied over time (Fig. 3). In 1991, vestimentiferan communities (IV, V and VI) occupied more than $50 \%$ of the surface of the sulfide complex (Fig. 3A). In 1994 community III was dominant (Fig 3B) and in 1995, communities $1 \mathrm{Il}$ and VI covered $>71 \%$ of occupied surfaces (Fig 3C). The 2 communities (II and IV) occupying the smallest surface area in 1991 had disappeared by the end of the study. Communities III and VI showed large fluctuations in total area in the 1991-1994 and 1994-1995 intervals, while community I progressively decreased in area and community $\mathrm{V}$ remained relatively stable (in total surface) (Table 1).

Community distribution patterns varied through time on different parts of the S\&M complex (Fig. 3). The Dog Head structure had significant uncolonized surfaces and was covered by 4 communities (I, II, III and VI) in 1991 (Fig. 3A). In 1995, most of the surface was colonized by community III (Fig. 3C). The area surrounding the flange pool, active in 1991, was colonized by communities I, II and III. In 1994, the pool had disappeared and community IV had replaced the previous ones. In 1995, a new flange pool environment is present on Dog Head, and community I had replaced the previous communities (III, IV and VI) (Fig. 3C).

The Northern Cluster was very poorly populated in 1991 (Fig 3A). It evolved from dominance by community VI with uncolonized surfaces to an extensive coverage by community III in 1994 (Fig. 3B). In 1995, a meter-wide apron of sulfide debris from the main edifice lay at the base of the western side of S\&M just below the Northern Spire (Fig, 2C). This 'collapse slide' swept away parts of the colonizing fauna, leaving a bare surface covered by tube worm debris (Fig. 3C). The newly formed active features (beehives and flanges) at the base of the north-west side of S\&M in 1995 were colonized by type I and II communities (Fig. 3C). 
Southern Cluster was almost entirely colonized in 1991 (communities I, II, III and V). Communities I and $\mathrm{V}$ dominated with $63 \%$ coverage of the surface. In 1991 and 1994, the top of Southern Cluster was dominantly colonized by community I whereas in 1995 a luxuriant field of vestimentifera (community V) covered most of the surface (Fig. 3C). Most of this tube worm community was severely perturbed within $4 \mathrm{~d}$ of a ROV-provoked chimney reactivation in July 1995. Newly formed spires were rapidly colonized by palm worms Paralvinella palmiformis and sulfide worms Paralvinella sulfincola. Migration of palm worm adults was observed within minutes of the perturbation whereas sulfide worm reaction appeared to be slower. Two months later (September 1995), much of the vestimentiferan community (V) had disappeared and the top of Southern Cluster was heavily colonized by communities I and II. The formation of a smoking flange at the base of Southern Cluster (southwest) was accompanied by the extinction of the existing community $\mathrm{V}$. Blackened tube worms were often seen around reactivated or active areas suggesting that the environment became too harsh for survival of the community.

The basaltic seafloor at the northern edge of S\&M was colonized by senescent vestimentiferan bushes (community VI) in 1991 (Fig. 3A). In 1994, we observed a partial reactivation of fluid flow in this area, designated Palm Springs (Fig. 3B). Empty vestimentiferan tubes were overgrown by white bacterial mats and surrounded by dispersed palm worm patches. In 1995, community III had taken over all of the reactivated zone (Fig 3C). This suggests a sequence whereby adult mobile organisms (palm worms and gastropods) migrated first to the new active habitat, with tube worm colonization from larval settlement occurring more slowly (tube worm adults first appeared during the 1994-1995 interval).

\section{Community changes}

Overall, community changes were substantial on the S\&M edifice with $68 \%$ of the $0.25 \mathrm{~m}^{2}$ grid squares changing during the 1991-1994 interval and $88 \%$ in $1994-1995$ (Fig. 8A, B) There was no apparent trend to changes relative to the $\mathrm{Y}$ or $\mathrm{Z}$ axes (Fig. $8 \mathrm{~A}, \mathrm{~B}$ ). There was little difference in the numbers of grid squares changing composition in 1991-1994 versus 1994-1995 (1043 vs 1022). As a result, the apparent rate of change is greater for the shorter interval (1022 per year for $1994-1995$ vs 1043 per 3 yr for 1991-1994). The area of the structure showing the greatest contrast in transformations between the 2 time intervals was the top of Southern Cluster (right hand portions of Fig. 8A). Above the $8 \mathrm{~m}$ level, 20 to $40 \%$ of the grid squares changed in the 1991-1994 interval compared to 90 to $100 \%$ between 1994 and 1995 when a different community (V) took over the entire summit surface (Fig 8A). Major flow pattern changes occurred at the top of S\&M during the 1994-1995 interval (Fig. 5B, C), some of which can be attributed to perturbation by submersibles.

In the analysis of the fate of individual grid squares (Fig. 9), there was a noticeable trend for community III to remain stable and to take over grid squares occupied by other communities. Community I tended to be replaced by communities III, V or VI or remain the same (Fig. 9A). Community I was stable only in areas where visible structural and flow conditions stayed constant. Community II was only present in 1991 and appeared to be preferentially replaced by community III (Fig. 9B). Community III remained stable between 1991 and 1994, whereas during the 1994-1995 interval, it was more subject to change and primarily replaced by one of communities I, V or VI (Fig. 9C). Community IV was primarily replaced by community III
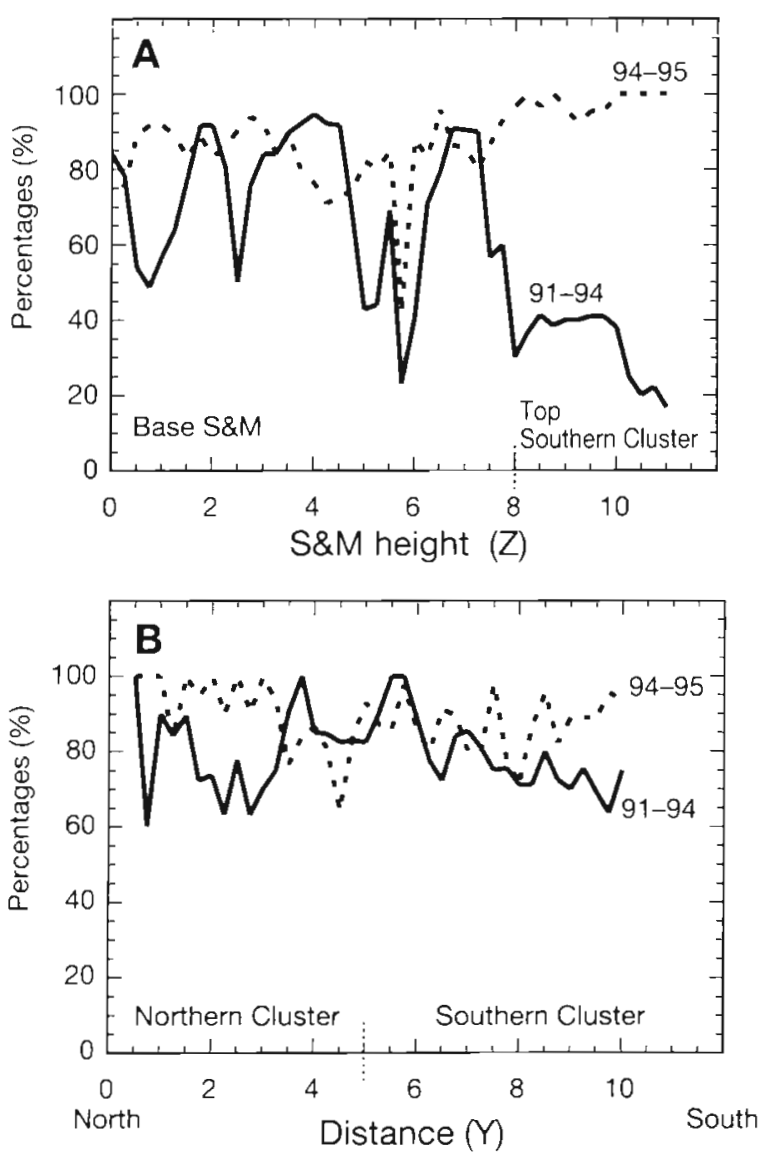

Fig. 8. Percentage of grid squares $(25 \times 25 \mathrm{~cm})$ on the west face of $S \& M$ changing surface attributes for the 2 time intervals studied: (A) relative to height of the structure $(\mathrm{Z})$; $(B)$ relative to north-south orientation (Y). Distances are in meters up (A) and south (B) from origin in Fig. 4 

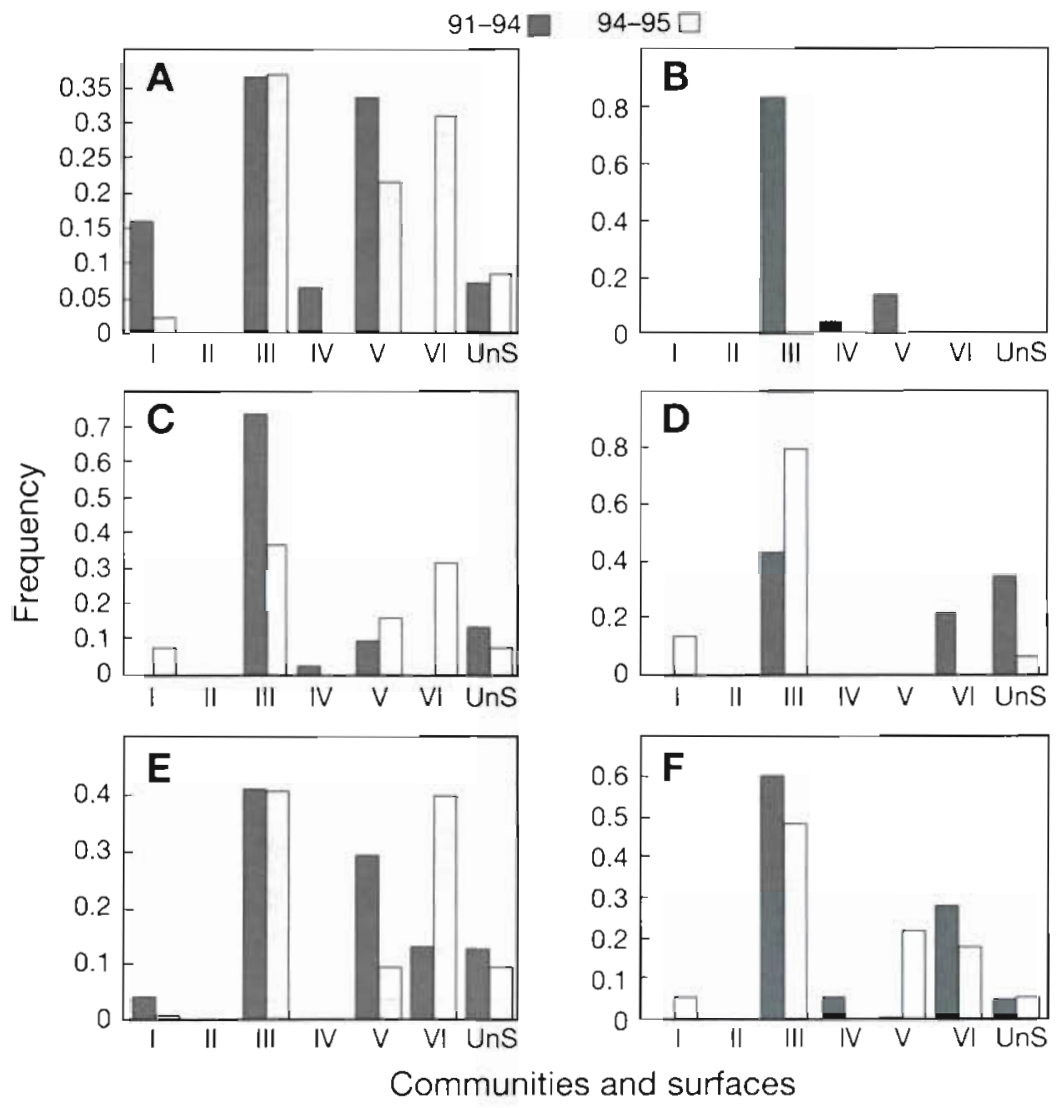

Fig. 9. Fate of colonized grid squares on the western face of $S \& M$ for the 2 studied intervals. Vertical axes show relative frequency by which grid squares dominated by a given community remained unchanged or were dominated by a different community at the return visit (i.e. in 1994 for 1991-1994 and in 1995 for 1994-1995): (A) community I, (B) community II, (C) community III, (D) community IV, (E) community V, (F) community VI. (I to VI: faunal communities, UnS: uncolonized surfaces). Community II was observed only in 1991. Y-axes have different scales
(Fig. 9D). Community $\mathrm{V}$ remained unchanged or was replaced by community III or community VI, and to a lesser extent by uncolonized surfaces (Fig. 9E). In the 1991-1994 interval, community VI, when not stable, tended to be replaced by community III such as in the reactivation sequence described for Palm Springs. In the following interval (1994-1995) there was substantial replacement of community VI by community III and V again suggesting a reactivation of flow (Fig. 9F). Grouping communities with adult vestimentifera (IV, V and VI) showed that $60 \%$ of surfaces occupied by vestimentifera contained vestimentifera at the following visit, for both time intervals.

\section{Habitat and community links}

Uncolonized surfaces were mostly colonized by mobile species communities, principally the palm wormdominated community III (Fig. 10A). It is worth noting that communities $\mathrm{V}$ and VI also appeared on uncolonized surfaces over the 1994-1995 interval. The transition from community III to communities $\mathrm{V}$ or VI implies colonization by tube worm larvae, growth of tube worms to several centimeters in length and then either continued
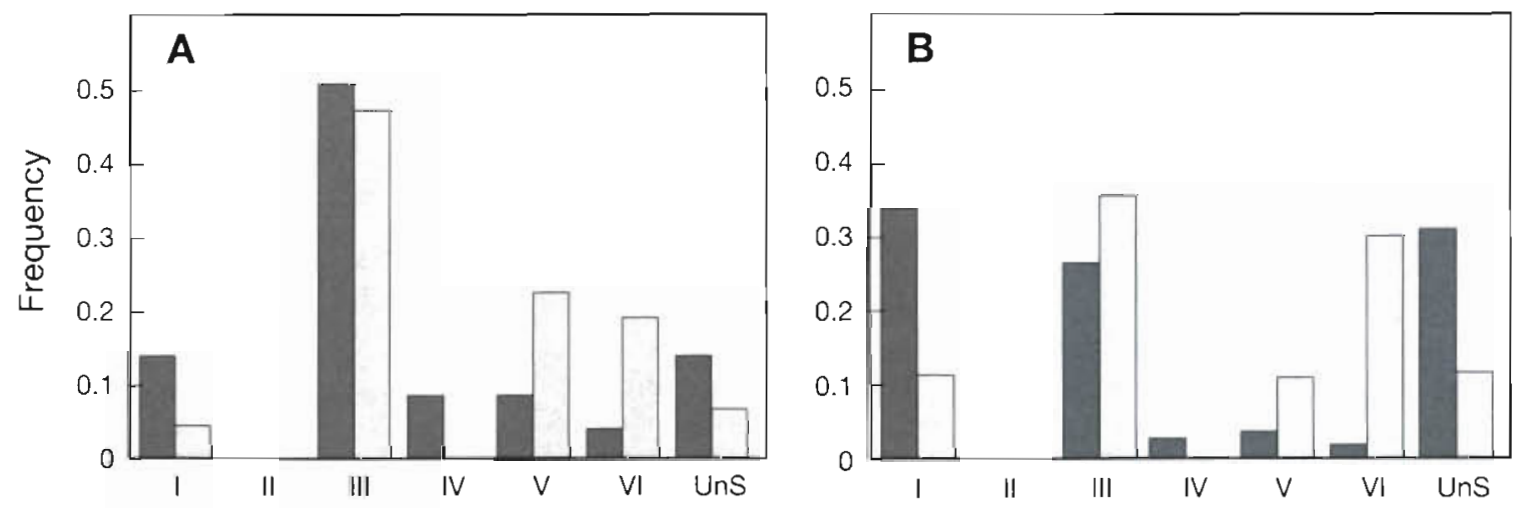

$91-94$

$94-95$

Communities and surfaces

Fig. 10. Dynamics of uncolonized and newly-formed surfaces for the 2 time intervals studied, as determined from gridded faunal maps (Figs. 3 \& 4). (A) Uncolonized surfaces - relative frequency by which uncolonized grid squares remained bare or were colonized by 1 of the 6 faunal communities during each observational interval. (B) New surfaces-during each time interval new surfaces were formed. Graph shows relative frequency by which new surfaces (grid squares) appeared bare or were colonized by different communities. (I to VI: faunal communities, UnS: uncolonized surfaces) 
growth (community $V$ ) or senescence as a resuit of deteriorating living conditions (community VI). Displacement of tube worm debris and lateral growth of adjacent communities could also bring adult tube worms to uncolonized surfaces. Few uncolonized surfaces remained bare throughout the entire study period (Fig 10A).

In general, newly formed surfaces were either colonized by mobile species (communities I and III) or remained uncolonized (UnS) (Fig. 10B). For example, the tops of newly formed flanges on Southern Cluster and Northern Cluster base were systematically colonized by sulfide worms where previously communities IV or VI had been dominant. Community VI was also a significant occupant of newly-formed surfaces in 1995, suggesting a rapid evolution through communities IV and V followed by a sudden modification of activity (Fig. 10B).

Communities I and III were also commonly associated with visible flow features (smokers and shimmering surfaces). Shimmering surfaces were primarily occupied by community III (54\% of 1991-1995 total, Fig. 5D) and community I (20\% of 1991-1995 total, Firg. 5D) We nhserved a positive correlation ( $r=0.98$, not significant) between the number of black smokers in each year of the study and the total surface colonized by community $\mathrm{I}$.

\section{DISCUSSION}

\section{S\&M. habitat}

The overall morphology of S\&M and the distribution of the different types of venting make this edifice different from the larger, mature sulfide-sulfate-silica structures described by Delaney et al. (1992). Extensive areas of diffuse flow sustained communities of tube worms directly on the basaltic floor surrounding the edifice, suggesting that the subsurface stockwork of S\&M was not yet the silicified, well-sealed, pipe-like zone proposed by Hannington et al. (1995) for Endeavour-type sulfide structures. Furthermore, although black smokers were found at the top of the structure as on most other edifices in the vent field, S\&M lacked a significant barren zone at the base (Delaney et al. 1992, Robigou et al. 1993). The small bulbous flanges on S\&M seemed to be at an early stage of evolution and lacked a well-established pool as observed elsewhere in the Main Endeavour Field. They were texturally similar to beehive structures (Fouquet et al. 1993) and exhibited rhythmic horizontal layering. Taken together these observations suggest that S\&M represents an earlier stage in the evolution of the more typical, larger sulfide structures described in this hydrothermal vent field (Delaney et al. 1992, Hannington et al. 1995).

\section{Spatio-femporal heterogeneity of biological communities}

The spatial distribution of faunal communities on S\&M was considerably more heterogeneous than described in previous studies (Fustec et al. 1987, Tunnicliffe \& Juniper 1990, Hannington \& Juniper 1992, Segonzac et al. 1993), all of which propose links between community and habitat to explain spatial heterogeneity. All communities were observed at all vertical or horizontal levels on the sulfide structure and most (except communities I and II) also occurred in diffuse-flow environments on the basaltic seafloor. Horizontal layering of faunal communities, particularly noticeable on Southern Cluster, may be related to irregular vertical growth of the edifice, and resulting effects on flow regimes. Communities were distributed in decimeter-scale patches, suggesting a similar distribution for habitat conditions and perturbations.

Some fauna-habitat links, often flow related, were particularly evident in our study of S\&M. Newlyformed high-temperature habitats such as beehives on the Southern and Northern Clusters and flange lips around Dog Head were systematically colonized by communities I and/or II. These actively changing features were good indicators of the presence of Paralvinella sulfincola populations (communities I and II) (Tunnicliffe et al. 1993). Community II (Paralvinella palmiformis and $P$. sulfincola) occurred in habitats characterized by centimeter-scale variation in flow and temperature regimes. Community III clearly monopolized visible shimmering surfaces while communities IV, V and VI generally colonized lower temperature, weaker flow habitats.

\section{Flow pattern changes}

Identifiable faunal and geological changes on this complex sulfide structure appeared to reflect flow modifications. The most noticeable evolution that occurred on S\&M was the change in venting style at the structure scale. Hydrothermal activity evolved from focused flow through many black smokers in 1991 to extensive diffuse flow activity in 1995. Progressive clogging of several main conduits within the S\&M structure may have been instrumental in the observed overall flow change. This assumes that hydrothermal fluid supply to S\&M from the subsurface remained nearly constant over the study period. As discussed by Tivey (1995), precipitation of sulfide minerals in chimneys reduces the effective diameter of the internal conduits. As internal conduit diameter decreases, flow pressure builds up within sulfide edifices, and hydro- 
thermal fluids are locally redirected outward across chimney walls (Delaney et al. 1992, Tivey 1995). This phenomenon can account for the increase in 'shimmering water' area on the sulfide structure during the study period as well as the appearance of beehives and small flange pools in the vicinity of recently extinct black smoker chimneys. The formation of Palm Springs (Figs. 2 \& 3), a new diffuse flow site on the north side of the structure, further supports such flow redirection, not only through the porous sulfides that form the structure itself but through the near-surface plumbing on the adjacent seafloor

Flow redirection and conduit restrictions may have produced pooling of hydrothermal fluid within the mass of the sulfide structure. Escape of 'internallypooled' fluids at different levels on S\&M could thus occur and would vary with local porosity and near surface mineralogy. Community $I$ is known to occupy marcasite sealed surfaces where temperatures are high but where underlying fluids seep very slowly through the marcasite crust (Juniper et al. 1992). Advection of pooled fluids through zones of more porous material could result in local entrainment of seawater, and produce cooler, high-volume shimmering flow zones. Diffuse flow of hydrothermal and cold seep fluids through sediments and resultant seawater entrainment has been modeled (Henry et al 1992, 1996, Goodfellow \& Peters 1994, Grehan \& Juniper 1996). However, the relationship of micro-scale diffuse flow through sulfide structures to bulk physical properties of deposited minerals has not been examined either in models or from in situ observations and sampling.

Hydrothermal processes can also be influenced by biogenic structures and materials. One important aspect of colonized edifices at northeast Pacific vents is the thickness of the faunal overgrowth that covers the outer surface of most active chimneys (Juniper \& Sarrazin 1995). This faunal overgrowth may locally modify flow patterns, fluid composition, mineral precipitation and the degree of hydrothermal fluid mixing with seawater (Juniper et al. 1988, 1992, Segonzac et al. 1993, Juniper 1994, Hannington et al. 1995, Juniper \& Martineu 1995, Juniper \& Sarrazin 1995). Johnson et al. (1994) have directly demonstrated effects of biological processes on fluid properties at vents.

\section{Effect of perturbations on communities}

Rapid community changes and colonization by different species following the creation or destruction of a habitat demonstrate the ability of the vent fauna to exploit a very dynamic environment (Juniper et al. 1992, Juniper 1994). Perturbations create opportunities for mobile species to colonize new surfaces suited to their physiological and nutritional requirements. Migration of mobile species was observed within minutes of disturbances on S\&M. For example, the polychaete Paralvinella palmiformis, the limpet Lepetodrilus fucensis and 2 small snails (Depressigyra globulus and Provanna variabilis) were the first to exploit flow reactivation in the Palm Springs area (Fig 3), while sessile species were not observed until a year later. P. palmiformis in particular appears to have an opportunistic exploration strategy that enables adult individuals to seek out and colonize newly-available surfaces. Several authors have observed rapid colonization of reactivated or new hydrothermal surfaces by alvinellid polychaetes (Bowers et al. 1985, Fustec et al. 1987, Tunnicliffe \& Juniper 1990, Gaill \& Hunt 1991, Juniper et al. 1992)

Perturbations also had negative effects on both mobile and sessile organisms. Unstable substrata, such as the top of Northern Cluster in 1991, were almost devoid of any type of fauna. Repeated structural failures of this chimney likely prevented successful colonization. Sessile chimney organisms dependent upon hydrothermal activity are most vulnerable to environmental change. Slow recolonization of disturbed vents by tubes worms has been interpreted as evidence that recruitment is not continuous and that the animals have a poor ability to maintain their populations once disturbed (Tunnicliffe et al. 1990). Extinction of a tube worm community (community $V$ ) on Southern Cluster within $4 \mathrm{~d}$ of a sampling-provoked disturbance illustrates the fragility of flow conduits and dependent biological communities. Mobile organisms reacted to this event by quickly colonizing newly-activated areas. Similar events on Axial Seamount were followed by the same drastic community changes (Tunnicliffe 1990).

Small scale perturbations are a likely factor behind the observed patchy distribution of faunal communities on S\&M. Opportunistic recolonization of disturbed areas by adults and larvae can produce a mosaic of patches, the dynamics and diversity of which depend on factors such as the magnitude and frequency of disturbance events, and the timing of events relative to availability of colonists (Mullineaux \& France 1995).

Rapid colonization of newly-formed surfaces is evidence that space is a limiting resource for vent organisms. Inactive surfaces that remain uncolonized are probably unable to support chemolithoautotrophic organic matter production or provide access to it (e.g. suspension feeding). High-temperature features such as beehives, flange rims, flange pool and black smoker surfaces are generally devoid of fauna. These environments are probably too extreme (high-temperature, hot-fluid overflow) or unstable. 


\section{Community evolution: succession?}

One of the goals of this study was to determine whether community changes on sulfide edifices are driven by environmental changes, by biological succession or by stochastic events. Biological succession usually implies a predictable, orderly or progressive change in species composition (Connell 1989, Bell et al. 1991). It is of major interest to ecologists since known succession patterns can be used to predict the future of communities. In the marine environment, several studies of hard substrate sessile organisms have documented non-successional changes (in Connell 1989). Observed patterns of community change on S\&M are summarized in Fig. 11A. Despite a number of apparent trends, canonical redundance analysis (Legendre \& Legendre 1983) of the S\&M data indicated that community changes did not follow any directional, ordered pattern in the 2 time intervals considered (analysis not shown). Community dynamics on S\&M corresponded in many ways to the 'chronic disturbance model' developed by Horn (1976) for plant communities (Fig. 11B), where chronic patchy disturbances create situations where any species, if adult or larval recruits are available, can invade an opening resulting from the death of any other species. Abrupt and frequent physical environment changes thus dictate community distribution patterns in both time and space. For example, the frequent occurrence of community III combined with its tendency to replace all other communities suggest that this community is opportunistic and will colonize active (and reactivated) habitats on almost all sulfide substrata.

The apparent randomness of biological change at the 1 to 3 yr time intervals does not exclude the possibility of more rapid successional processes. Observa- tions on the summit of Southern Cluster and elsewhere indicate that the entire process of formation of new shimmering surfaces and growth of tube worms to adult size can occur within less than $1 \mathrm{yr}$. The observed link between black smoker abundance and community I suggests that Paralvinella sulfincola is a primary colonizer of new high-temperature surfaces, as observed in a month-long time lapse camera deployment by Juniper et al. (1992). It is unlikely that larval vestimentifera would become established on surfaces before mobile polychaetes and limpets, so that succession through communities III, IV and V on newly formed or reactivated surfaces is probable. In Fig. 11C, we propose a dynamic succession model where hydrothermal community changes are driven by flow modifications and biological processes. The model includes the simplest case of progressive transition from community I through community VI, from the formation of new high temperature surfaces, followed by a gradual decrease of flow and eventual extinction. Within this basic model we identify 2 transitions that are primarily mediated by biological processes (Fig. 11C). Juniper et al. (1992) link formation of marcasite crusts on new chimney surfaces to mucus secretion by Paralvinella sulfincola (community I). Community II as observed here consisted of marcasite outgrowths colonized by $P$. palmiformis, surrounded by $P$. sulfincola. We interpret this as evidence that habitat modification by sulfide worms (marcasite crust formation) precedes palm worm colonization. Second, the transition from community IV to $\mathrm{V}$ is primarily the result of tube worm growth, as discussed above. To this basic model we also add the effect of flow increases to account for observed reactivation of surfaces. Finally, perturbation events (natural or anthropogenic) can cause abrupt

\section{A. Observed community changes on S\&M}

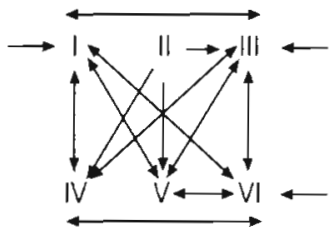

B. Chronic disturbance model

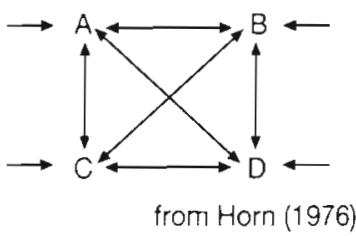

C. Hypothesized dynamic succession model

New high-temperature surface

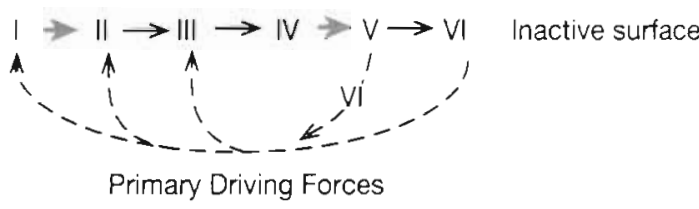

$\rightarrow$ Flow decrease

$\leftarrow-$ Flow increase

$\rightarrow$ Biological processes
Fig. 11. Observed and proposed dynamic patterns for hydrothermal edifice communities: (A) Community changes on S\&M at 1 to $3 \mathrm{yr}$ time scales, (B) chronic disturbance model developed by Horn (1976), (C) hypothesized dynamic succession model. Primary driving forces for community changes are flow modifications and biological processes such as growth and habitat alteration (biomineralization, flow modification, etc.). Community disappearance can occur at any point in the sequence through stoppage of fluid flow or sudden hightemperature reactivation. Communities I to III are dominated by mobile species and likely to migrate in response to flow variations. Only tube-worm dominated community $V$ produces a visible thanatocenosis (community VI). The 2 pathways downstream from community $V$ Iepresent death due to flow extinction or intense reactivation. Perturbations that do not affect flow regimes should permit progressive recolonization by the original community 
flow changes that initiate jumps in either direction from one position in the community sequence to a more distant one. Our data suggest that multiple community transitions are common at sub-annual time scales as a result of both gradual environmental change and perturbations.

\section{CONCLUSION}

The magnitude of small-scale heterogeneity in these sulfide edifice communities and the extent of change between years was surprising. To our knowledge, major perturbations caused by submersibles during the study period were limited to the summit of Southern Cluster where effects on local faunal composition and flow characteristics were substantial. On the other hand, we observed several major redirections of fluid flow (Palm Springs reactivation, reduction in number of smokers, overall increase in shimmering surfaces) and resultant faunal changes that are best explained by processes occurring within the sulfide structure itself. The importance of minor, decimeter-scale contact between submersibles and sulfide surfaces is difficult to quantify, although we suspect it to be negligible compared to natural disturbances. An accurate appreciation of fine scale dynamics will only be possible at sites designated for non-interventive studies.

Abiotic factors appear to represent the primary driving forces for change in hydrothermal community structure on active sulfide structures, as is the case for many severely perturbed hard substrate communities. Nevertheless, the relative importance of physical versus biological control of community succession can only be rigorously evaluated from direct observation of organism interactions. This will require experimental manipulation of the biological and/or physical environment

Vents are interesting areas for research on the influence of disturbance on biological diversity and succession patterns, and for study of organism and community adaptations to extreme and dynamic habitats. They are 'isolated' from most anthropogenic perturbations (pollution, global warming, coastal development, etc.) and offer discrete microcosms for observatory studies. While manipulative experiments are still limited by technology, the hydrothermal milieu could be a useful proving ground for ecological hypotheses developed in other habitats.

Acknowledgements. This work would not have been possible without the field support by the pilots of ROPOS, Alvin and Jason and the crews of the CSS 'John P. Tully' and the RV 'Atlantis II'. This research was sponsored by NSERC-Canada, Fisheries and Oceans Canada and the National Science Foun- dation. J.S. was supported by post-graduate fellowships from NSERC (Canada), FCAR (Québec) and GÉOTOP (UQAM). We are particuldrly grateful to Dr Pierre Legendre for his help with canonical analyses and to Drs Verena Tunnicliffe and Margaret Tivey for their suggestions and comments on the manuscript. Dr Mark Hannington kindly provided drawings of S\&M from 1991 Jason and Alvin imagery, and Enriette Gagnon aided in drafting of Fig. 3. The UQAM. Décanat des Etudes Avancées, provided support for publication of color figures. Four anonymous reviewers are thanked for their constructive input.

\section{LITERATURE CITED}

Bélanger C, Cardinal A (1977) Stades initiaux de colonisation de substrats durs dans la Baie-des-Chaleurs, Québec. Mar Biol 44:27-38

Bell SS, McCoy ED, Mushinsky HR (1991) Habitat structure: the physical arrangement of objects in space. In: Bell $\mathrm{S}$, McCoy ED, Mushinsky HR (eds) Population and community biology series. Chapman and Hall, New York

Boulding EG, Van Alstyne KL (1993) Mechanisms of differential survival and growth of two species of Littorina on wave-exposed and on protected shores. J Exp Mar Biol Ecol 169(2): 139-166

Bowers IS, Von Damm KL, Edmond JM (1985) Chemical evolution of mid-ocean ridge hot springs. Geochim Cosmochim Acta 49:2239-2252

Butterfield DA, McDuff RE, Mottl MJ, Lilley MD, Lupton JE, Massoth GJ (1994) Gradients in the composition of hydrothermal fluids from the Endeavour segment vent field: phase separation and brine loss. J Geophys Res 99(B5):9561-9583

Bythell JC, Gladfelter EH, Bythell M (1993) Chronic and catastrophic natural mortality of three common Caribbean reef corals. Coral Reefs 12:143-152

Chapman MG, Underwood AJ (1994) Dispersal of the intertidal snail, Nodilittorina pyramidalis in response to the topographic complexity of the substratum. J Exp Mar Biol Ecol 179:145-169

Chevaldonné P, Jollivet D (1993) Videoscopic study of deepsea hydrothermal vent alvinellid polychaete populations: biomass estimation and behaviour. Mar Ecol Prog Ser 95: $251-262$

Connell JH (1972) Community interactions on marine rocky intertidal shores. A Rev Ecol Syst 3:169-191

Connell JH (1978) Diversity in tropical rain forest and coral reefs. Science 199:1302-1310

Connell JH (1985) The consequences of variation in initial settlement vs. post-settlement mortality in rocky intertidal communities. J Exp Mar Biol Ecol 93:11-45

Connell JH (1989) Change and persistence in some marine communities. In: Gray AJ, Crawley MJ, Edwards PJ (eds) Colonization, succession and stability. The 26th Symposium of the British Ecological Society. Blackwell Scientific Publications, Oxford, p 339-352

Dai CF (1993) Patterns of coral distribution and benthic space partitioning on the fringing reefs of Southern Taiwan. PSZN I: Mar Ecol 14(3):185-204

Dayton PK (1970) Competition, predation, and community structure: the allocation and subsequent utilization of space in a rocky intertidal community. PhD thesis, University of Washington, Seattle

Dayton PK (1971) Competition, disturbance, and community organization: the provision and subsequent utilization of space in a rocky intertidal community. Ecol Monogr 41(4): $351-389$ 
Delaney JR, Flange, Crest91 Teams (1991) JASON/ALVIN operations on the Endeavour Segment, Juan de Fuca Ridge - summer 1991. EOS 72:231

Delan : JR, Hildebrand J (1993) RIDGE Observatory Experiment (ROBE), Summary report of a workshop held February 18-20 1993, University of Washington, Seattle, WA. Ridge Office, University of New Hampshire, Durham

Delaney JR, McDuff RE, Tivey MK, Lupton JE (1989) Measurements of $400^{\circ} \mathrm{C}$ hydrothermal fluids and tempora] variability in the Endeavour vent fjeld. EOS 70:1163

Delaney JR, Robigou V, MCDuff RE, Tivey MK (1992) Detailed geologic relationships of a vigorous hydrothermal system. the Endeavour vent field, northern Juan de Fuca Ridge. J Geophys Res 97:19663-19682

Dethier MN (1994) The ecology of intertidal algal crusts: variation within a functional group. J Exp Mar Biol Ecol 177 $37-71$

Fouquet Y, Wafik A, Cambon P, Mevel C, Meyer G, Gente P (1993) Tectonic setting and mineralogical and geochemical zonation in the Snake Pit sulfide deposit (Mid-Atlantic Ridge at $23^{\circ} \mathrm{N}$ ). Econ Geol 88:2018-2036

Fustec AD, Desbruyères D, Juniper SK (1987) Deep-sea hydrothermal vent communities at $13^{\circ} \mathrm{N}$ on the east Pacific rise: microdistribution and temporal variations. Biol Oceanogr 4(2):121-164

Gaill F, Hunt S (1991) The biology of annelid worms from high temperature hydrothermal vent regions. Rev Aquat $\mathrm{Scl}$ $4(2-3): 10 \bar{f}-13 \hat{z}$

Glynn PW (1976) Some physical and biologıcal determinants of coral communty structure in the eastern Pacific. Ecol Monogr 46:431-456

Goodfellow WD, Peters JM (1994) Geochemistry of hydrothermally altered sediment, Middle Valley, Northern Juan de Fuca Ridge. In: Davis EE, Mottl MJ, Fisher AT et al. (eds) Proceedings of the Ocean Drilling Program (ODP). College Station, TX, Sci Results 139:207-289

Grehan A, Juniper SK (1996) Clam distribution and subsurface hydrothermal processes at Chowder Hill (Middle Valley), Juan de Fuca Ridge. Mar Ecol Prog Ser 130 $105-115$

Hannington MD, Juniper SK (1992) The ecology and geological evolution of large sulfide structures: scaling up from chimney models. RIDGE Events, Vol 30. Ridge Office, University of New Hampshire, Durham, p 38-42

Hannington MD, Jonasson IR, Herzig PM, Petersen S (1995) Physical and chemical processes of seafloor mineralization at mid-ocean ridges. In: Humphris SE, Zierenberg RA, Mullineaux LS, Thomson RE (eds) Seafloor hydrothermal systems: physical, chemical, biological, and geological interactions. Geophys Monogr Ser 91, American Geophysical Union (AGU), Washington, DC, p 115-157

Henry P, Foucher JP, Le Pichon X, Sibuet M. Kobayashi K Tarits P. Chamot-Rook N, Furuta T. Schultheiss P (1992) Interpretation of temperature measurements from the Kaiko-Nankai cruise: modeling of fluid flow in clam colonies. Earth Planet Sci Lett 109:355-371

Henry $P$, Le Pichon X, Lallemant S, Lance S, Martin JB, Foucher JP, Fiala-Medion A, Rostek F, Guilhaumou V Pranal V, Castrec $M$ (1996) Fluid flow in and around a mud volcano field seaward of the Barbados accretionary wedge: results from Manon cruise. J Geophys Res 101(B9) $20297-20323$

Hessler RR, Smithey WM, Boudrias MA, Keller CM, Lutz RA, Childress JJ (1988) Temporal change in megafauna at the Rose Garden hydrothermal vent (Galapagos rift; eastern tropical Pacific). Deep Sea Res 35 (10/11): $1681-1709$
Horn HS (1976) Succession principles and applications. In: May RM (ed) Theoretical ecology. WB Saunders, Philadelphia, p 187-204

Johnson KS, Childress JJ, Hessler RR, Sakamoto-Arnold CM, Beehler CL (1988a) Chemical and biological interactions in the Rose Garden hydrothermal vent field, Galapagos spreading center. Deep Sea Res 35(10/11):1723-1744

Johnson KS, Childress JJ, Beehler CL (1988b) Short-term temperature variability in the Rose Garden hydrothermal vent field: an unstable deep-sea environment. Deep Sea $\operatorname{Res} 35(10 / 11): 1711-1721$

Johnson KS, Childress JJ, Beehler CL, Sakamoto CM (1994) Biogeochemistry of hydrothermal vent mussel communities: the deep-sea analogue to the intertidal zone. Deep Sea Res 41(7):993-1011

Juniper SK, Tunnicliffe V, Fontaine AR (1988) Biological influences on mineral deposition at deep-sea hydrothermal vents. NOAA National Undersea Research Program Report 88-4:99-118

Juniper SK, Jonasson IR, Tunnicliffe V, Southward AJ (1992) Influence of a tube building polychaete on hydrothermal chimney mineralization. Geology (Boulder) 20:895-898

Juniper SK (1994) Ecology and biogeochemistry of Paralvinelld sulfincola at northeast Pacific hydrothermal vents: review and comparison with Alvinella spp. of the east Pacific rise. In: Dauvin JC, Laubier L, Reish DJ (eds) Actes de la 4ème conférence internationale des polychètes. Mém Muc Natl Hist Nat Not Syst 162:453-462

Juniper SK, Fisher $C$ and the shipboard scientific party of BioROPOS 94: Galley A, McArthur A, MacDonald I, Santaguida F, Sarrazin J, Scott KT, Tunnicliffe V, Urcuyo I, Williams T (1994) A biological observatory at Endeavour Segment, Juan de Fuca Ridge. InterRidge News, Vol 3(2). InterRidge Office, Université Pierre et Marie Curie, Paris, p 23-25

Juniper SK, Martineu P (1995) Alvinellids and sulfides at hydrothermal vents of the eastern Pacific: a review. Am Zool 35:174-185

Juniper SK, Sarrazin J (1995) Interaction of vent biota and hydrothermal deposits: present evidence and future experimentation. In: Humphris SE, Zierenberg RA, Mullineaux LS, Thomson RE (eds) Seafloor hydrothermal systems: physical, chemical, biological, and geological interactions. Geophys Monogr Ser 91, American Geophysical Union (AGU), Washington, DC, p 178-193

Juniper SK. Tunnicliffe $V(1997)$ Crustal accretion and the hot vent ecosystem. Phil Trans R Soc Lond Ser A 355: $459-474$

Karlson RH, Hurd LE (1993) Disturbance, coral reef communities, and changing ecological paradigms. Coral Reefs 12 : $117-125$

Kosku RA, Jonasson IR, Kadko DC, Smith VK, Wong FL (1994) Compositions, growth mechanisms, and temporal relations of hydrothermal sulfide-sulfate-silica chimneys at the northern Cleft Segment, Juan de Fuca Ridge. J Geophys Res 99(B3):4813-4832

Legendre L, Legendre P (1983) Écologie numérique: 2. La structure des données écologiques. Collection d'écologie, Les presses de l'université du Québec. Masson, Paris p $207-223$

Lilley MD. Feely RA, Trefry JH (1995) Chemical and biochemical transformations in hydrothermal plumes. In Humphris SE. Zierenberg RA, Mullineaux LS, Thomson RE (eds) Seafloor hydrothermal systems: physical, chemical, biological, and geochemical interactions. Geophys Monogr Ser 91. American Geophysical Union (AGU), Washington, DC, p 369-391 
Littler MM, Littler DS (1984) Relationship between macroalgal functional form groups and substrate stability in a subtropical rocky-intertidal system. J Exp Mar Biol Ecol $74: 13-34$

Lubchenco J, Menge BA (1978) Community development and persistence in a low rocky intertidal zone. Ecol Monogr 59:67-94

Massoth GJ, Milburn HB, Hammond SR, Butterfield DA, McDuff RE, Lupton JE (1989) The geochemistry of submarine venting fluids at Axial Volcano, Juan de Fuca Ridge: new sampling methods and a VENTS program ratıonale. In: De Luca MP, Babb ] (eds) Global venting, midwater, and benthic ecological processes. Natl Undersea Res Program Res Rep 88-4, Natl Oceanic and Atmos Admin, Silver Spring, MD, p 29-59

McDuff RE, Atnipp V, Wells J (1990) Time-series studies of fluid output from the Endeavour vent field. EOS 71:1619

McClanahan TR (1992) Epibenthic gastropods of the middle Florida Keys: the role of habitat and environmental stress on assemblage composition. J Exp Mar Biol Ecol 160(2): $169-190$

McGuinness KA (1988) Short-term effects of sessile organisms on colonization of intertidal boulders. J Exp Mar Biol Ecol 1 16:159-175

Menge BA (1976) Organization of the New England rocky intertidal community: role of predation, competition, and environmental heterogeneity. Ecol Monogr 46:355-393

Menge BA, Sutherland JP (1976) Species diversity gradients: synthesis of the roles of predation, competition, and temporal heterogeneity. Am Nat 110:351-369

Merge Group (1984) Regional setting and local character of a hydrothermal field/sulfide deposit on the Endeavour Segment of the Juan de Fuca Ridge. EOS 65:1111

Metaxas A, Scheibling RE (1993) Community structure and organization of tidepools. Mar Ecol Prog Ser 98:187-198

Metaxas A, Hunt HL, Scheibling RE (1994) Spatial and temporal variability of macrobenthic communities in tidepools on a rocky shore in Nova Scotia, Canada. Mar Ecol Prog Ser 105:89-103

Mullineaux LS, France SC (1995) Dispersal mechanisms of deep-sea hydrotherma] vent fauna. In: Humphris SE, Zierenberg RA, Mullineaux LS, Thomson RE (eds) Seafloor hydrothermal systems: physical, chemical, biological, and geological interactions. Geophys Monogr Ser 91, American Geophysical Union (AGU), Washington, DC, p $408-424$

Mullineaux LS, Peterson CH, Fisher CR (1996) Colonization of hydrothermal vents near $9^{\circ} 50^{\prime} \mathrm{N}$, East Pacific Rise: a cruise report from block party $1,2 \& 3$. InterRidge News, Vol 5(2). InterRidge Office, Université Pierre et Marie Curre, Paris, p 19-21

Nybakken JW (1988) Marine biology: an ecological approach, 2nd edn. Harper \& Row Publishers, New York

Paine RT (1966) Food web complexity and species diversity. Am Nat 100:65-75

Robigou V, Delaney JR, Stakes DS (1993) Large massive sulfide deposits in a newly discovered active hydrothermal system, the High-Rise Field, Endeavour Segment, Juan de Fuca Ridge. Geophys Res Lett 20:1887-1890

Rodriguez SR, Ojeda FP, Inestrosa NC (1993) Settlement of benthic marine invertebrates. Mar Ecol Prog Ser 97: $193-207$

Rogers CS (1993) Hurricanes and coral reefs: the intermediate disturbance hypothesis revisited. Coral Reefs 12:127-137

Sarrazin J, Juniper SK, Massoth GJ (1993) Using the ROPOS remote vehicle to study biological and physico-chemical zonation on hydrothermal chimneys. EOS $74(43): 560$
Schultz A, Delaney JR, McDuff RE (1992) On the partitioning of heat flux between diffuse and point source seafloor venting. J Geophys Res 97:12229-12314

Segonzac M, de Saint-Laurent M, Casanova B (1993) L'énigme du comportement trophique des crevettes Alvinocarididae des sites hydrothermaux de la dorsale médio-atlantique. Cah Biol Mar 34:535-571

Sheppard CRC (1982) Coral populations on reef slopes and their major controls. Mar Ecol Prog Ser 7:83-115

Small E, Gross ME (1985) Preliminary observations of protistan organisms, especially ciliates, from $21^{\circ} \mathrm{N}$ hydrothermal vent site. Bull Biol Soc Wash 6:401-410

Sousa WP (1979) Disturbance in marine intertidal boulder fields: the nonequilibrium maintenance of species diversity. Ecology 60(6):1225-1239

Southward EC. Tunnicliffe V, Black M (1995) Revision of the species of Ridgeia from northeast Pacific hydrothermal vents, with a redescription of Ridgeia piscesae Jones (Pogonophora: Obturata $=$ Vestimentifera). Can J Zool 73 : $282-295$

Tanner JE, Hughes TP, Connell JH (1994) Species coexistence, keystone species, and succession: a sensitivity analysis. Ecology 75(8):2204-2219

Thomson RE, Delaney JR, McDuff RE, Janecky DR, McClain JS (1992) Physical characteristics of the Endeavour Ridge hydrothermal plume during July 1988. Earth Planet Sci Lett 111:141-154

Tivey MK, Delaney JR (1986) Growth of large sulfide structures on the Endeavour segment of the Juan de Fuca Ridge. Earth Planet Sci Lett 77:303-317

Tivey MK (1995) Modeling chımney growth and associated fluid flow at seafloor hydrothermal vent sites. In: Humphris SE, Zierenberg RA, Mullineaux LS, Thomson RE (eds) Seafloor hydrothermal systems: physical, chemical, biological, and geological interactions. Geophys Monogr Ser 91. American Geophysical Union (AGU), Washington, DC, p $158-177$

Tunnicliffe $V$ (1990) Observations on the effects of sampling on hydrothermal vent habitat and fauna of Axial Seamount, Juan de Fuca Ridge. J Geophys Res 95: 12961-12966

Tunnicliffe V, Garrett JF, Johnson HP (1990) Physical and biological factors affecting the behaviour and mortality of hydrothermal vent tubeworms (vestimentiferans). DeepSea Res 37(1):103-125

Tunnicliffe V, Juniper SK (1990) Dynamic character of the hydrothermal vent habitat and the nature of sulphide chimney fauna. Prog Oceanogr 24:1-13

Tunnicliffe $V$ (1991) The biology of hydrothermal vents: ecology and evolution. Oceanogr Mar Biol A Rev 29:319-407

Tunnicliffe $V$, Desbruyères D, Jollivet D, Laubier L (1993) Systematic and ecological characteristics of Paralvinella sulfincola Desbruyeres and Laubier, a new polychaete (family Alvinellidae) from northeast Pacific hydrothermal vents. Can J Zool 71:286-297

Underwood AJ (1981) Structure of a rocky intertidal community in New South Wales: patterns of vertical distribution and seasonal changes. J Exp Mar Bıol Ecol 51:57-85

Van Dover CL (1995) Ecology of mid-Atlantic ridge hydrothermal vents. In: Parson LM, Walker CL, Dixon DR (eds) Hydrothermal vents and processes. Geological Society Spec Publ 87, London, p 257-294

Wilkinson CR, Evans E (1989) Sponge distribution across Davies Reef, Great. Barrier Reef, relative to location, depth, and water movement. Coral Reefs 8:1-7

Williams GA (1994) The relationship between shade and molluscan grazıng in structuring communities on a mo- 
derately-exposed tropical rocky shore. J Exp Mar Biol Ecol 178:79-95

Wootton JT (1993) Indirect effects and habitat use in an intertidal community: interaction chains and interaction modifications. Am Nat 141(1):71-89

This article was submitted to the editor
Young DK, Young MW (1978) Community structure of the macrobenthos associated with seagrass of the Indian river estuary, Florida. In: Coull BC (ed) Ecology of marine benthos. University of South Carolina Press, Columbia, p $359-376$

Manuscript first received: December 5, 1996 Revised version accepted: April 11, 1997 